\title{
Politik İstikrarsızlık ve Yolsuzluk iliş̧kisi: Bir Panel Veri Analizi
}

\author{
Relationship of Political Rights And Corruptıon: A Panel Data Analysis
}

\author{
Gökhan ERKAL ${ }^{1}$, Merter AKINCI ${ }^{2}$, Ömer YILMAZ ${ }^{3}$
}

\begin{abstract}
ÖZET
Politik istikrarsızlık ve yolsuzluk arasındaki ilişkiyi tespit etmeyi amaçlayan bu çalışmada 1995-2013 döneminde 31'i az gelişmiş, 91'i gelişmekte olan ve 51'i gelişmiş olmak üzere toplam 173 ülke için panel veri analizleri kullanılmıştır. Pedroni, Kao ve Johansen-Fisher panel eş-bütünleşme testi sonuçlarına göre politik istikrarsızlık ve yolsuzluk arasında uzun dönemli ilişki tespit edilmiştir. Ayrıca Granger nedensellik analizi bulguları ise politik istikrarsızığın, yolsuzluğun nedeni olduğunu göstermiştir. Sabit etkili model tahmin sonuçlarına göre politik istikrarsızlıkta meydana gelecek \%1'lik bir artış, yolsuzlukta \%0,0603'lük bir azalma meydana getirmektedir. Dolayısıyla, 1995-2013 döneminde ele alınan 173 ülkede politik istikrarsızlıktaki artışın yolsuzluğu arttırdığı sonucuna varılmıştır.
\end{abstract}

Anahtar kelimeler: Politik Istikrarsızlık; Yolsuzluk; Panel Veri Analizi; Granger Nedensellik; Panel Eş Bütünleşme Analizi.

\section{GiRiş}

Sosyal refah düzeyi üzerinde ters yönlü etkiler yaratan politik istikrarsızlık ve yolsuzluk arasındaki ilişkiler, toplumsal açıdan optimal-altı kamusal politikalara yol açan unsurlar olarak ekonomi literatüründe yer almaktadır. Ekonomik sistem içerisinde birbirleriyle güçlü bir bağlantı içinde olduğu vurgulanan ve çıkış noktasını büyüme ve politik istikrar/istikrarsızlık kaynağında bulan bu ilişkinin temeli, karşılıklı bir sebep-sonuç bağına dayanmaktadır. Bir taraftan istikrarsız bir politik çevre ile bütünleşen ekonomik belirsizlik süreci yatırım kapasitesi ile ekonomik kalkınma hızının yavaşlamasına yol açmakta, diğer taraftan da zayıf ekonomik performans kamu sektörünün çöküşünü hızlandırarak politik belirsizliği artırmaktadır. Temelini, kamu kesiminin politika uygulamalarındaki yüksek oranlı değişimin oluşturduğu belirsiz sosyoekonomik yapılanma ise muhtemel yeni bir hükümet düzeninin oluşmasına zemin hazırlamaktadır. Dolayısıyla, tüm ekonomik yapıya sirayet eden bu belirsiz yapı, özellikle riskten kaçan ekonomik birimlerin iktisadi faaliyetlerini sekteye uğratmakta ya da dış piyasalara yatırımı özendirerek ekonomiden çıkış sürecini hızlandırmaktadır (Alesina vd., 1992).

\begin{abstract}
This study unlike previous studies aims to identify only the relationship between political rights and corruption by using the datas of 31 the least developed, 91 developing and 51 developed countries for a total of 173 countries for analysis of panel data for the period of 1995-2013. According to the Pedroni and Kao panel cointegration test and the Johansen-Fisher panel cointegration test long-term relationships between the political rights and corruption variables were determined. In addition, the findings of Granger causality analysis showed that political rights causes to corruption. According to the results of the fixed effect model a $1 \%$ increase in the political rights causes a $0,0603 \%$ reduction in the corruption. Therefore, it was found that the rise in political rights increases corruption considered 173 countries for the period of 1995-2013.
\end{abstract}

Keywords: Political Rights; Corruption; Panel Data Analysis; Granger Causality; Panel Cointegration Analysis.

Ekonomik sistemi tahrip eden ve genellikle "özel çıkarlara dayalı kazanç elde edebilmek için kamusal birimler tarafından yapılan suiistimal" şeklinde tanımlanan yolsuzluk olgusu, politik istikrarsızlığın bir unsuru olarak ortaya çıkmaktadır. Kamusal sistemin etkin işleyişindeki aksaklıklar ile meydana gelen ve rantın olduğu her alanda kendini gösteren yolsuzluk, özellikle rant kollama faaliyetleri ile şekillenmektedir. Rant kollama faaliyetlerinin ana kaynağı ranta ulaşabilmenin mümkün olmasına bağlı olduğundan, politik istikrarsızlık ile başlayan yolsuzluk süreci kamusal yasaklamalar ve müdahaleler sonucunda ekonomik sistemde aşırı kârların varlığına dayanmaktadır. Tarifeler ve ithalat kotaları gibi çeşitli dış ticaret yasakları, sübvansiyonlar ve vergi indirimleri gibi sanayi politikaları, fiyat kontrolleri, çoklu kur uygulamaları ve kamusal denetime tabi kredi mekanizması gibi uygulamalar, politik istikrarsızlık ve yolsuzluk ilişkisine bağlı olarak ortaya çıkan optimal-altı piyasa işleyişinin örneklerini temsil etmektedir (Mauro, 1998). Kamusal verimsizliğe dayanan optimal-altı politika uygulamaları her şeyden önce ekonomik sistem üzerinde olumsuz etkiler yaratmaktadır. Özgürlükçü ilkelere ve serbest piyasa mekanizmasına odaklanmayan sistem

\footnotetext{
${ }^{1}$ Arş. Gör. Dr. , Atatürk Üniversitesi, iỉBF, Ekonometri Bölümü

${ }^{2}$ Arş. Gör. Dr. , Ordu Üniversitesi, Ünye iïBF, İktisat Bölümü

${ }^{3}$ Prof. Dr. , Atatürk Üniversitesi, ỉiBF, Ekonometri Bölümü
} 
yapısı ekonomideki teknik gelişim ile inovasyon süreçlerini engellemektedir. Iktisadi faaliyetlerini yerine getirebilmek için sahip oldukları kaynaklarını çeşitli yolsuzluk kalemlerine aktaran yatırımcılar ve sermayedar sınıfı, ekonomik verimliliği artıracak üretken yatırımlarını azaltmak zorunda kalmaktadırlar. Uzun dönemde üretim sürecine dahil edilecek girdiler ile üretilecek çıktı miktarının düşmesine yol açan bu süreç, ekonomik büyüme dinamizmini engellemektedir. Diğer taraftan, tüm yetenek ve gayretlerini optimal yatırım harcamalarından rant kollama faaliyetlerine yönelten üretken sınıf, büyüme süreci üzerinde ilave bir yük oluşturmaktadır. Ayrıca, politik istikrarsızlığa bağlı olarak ekonomik sistemin dinamik işleyişinin sekteye uğramasıyla büyük boyutlara ulaşan yolsuzluk hareketleri, ya özel çıkar ve baskı gruplarını oluşturmakta ya da mevcut grupların güçlenmesini sağlayarak toplumsal fırsat eşitsizliğine neden olmaktadır. Bir anlamda gelir eşitsizliğine de yol açan bu mekanizma, yapısal bozulmaların yanı sıra sosyo-politik istikrarsızlığı da beraberinde getirmektedir (Mo, 2001). Yasal sistemde bir zayıflığa da neden olan politik istikrarsızlık, mülkiyet haklarının güvence altında olma derecesini de gündeme getirmektedir. Yolsuzluğun beraberinde getirdiği mülkiyet haklarının korunmasına ilişkin zayıflık sermayenin marjinal verimliliğini azaltmakta ve mevcut sermayenin ülke dışına çıkışını özendirmektedir. Ülkenin riskli bir kimliğe bürünmesi ile birlikte ortaya çıkan belirsizlik ortamı popülist uygulamaları da beraberinde getirmekte ve özellikle seçim dönemlerinde kamusal sektörün kısa vadeli verimsiz yatırımlara yönelmesine neden olmaktadır. Kaynak kullanımında etkinliğin bozulmasına ve enflasyonist sürecin kendini göstermesine bağlı olarak belirsizlik ortamı daha da şiddetlenmektedir. Ayrıca, politik istikrarsızlık dönemlerinde yükselen enflasyon, faiz ve borç maliyetleri dolayısıyla özel yatırımlar üzerinde dışlama etkisi oluşmakta ve büyüme oranları düşmektedir (Şanlısoy ve Kök, 2010). İç piyasada reel ve finansal sektöre büyük bir darbe vuran bu durum, dış piyasalara da yansımakta ve düşen ihracat kapasitesi ile ülkeden çıkan sermayeye paralel olarak cari açık sorunlarının artmasına ve sürdürülemez boyutlara ulaşmasına yol açmaktadır. Verimsiz kamu kesiminden kaynaklanan bu istikrarsız yapı, kamusal hizmetlerin kalitesini düşürerek, vergi gelirlerinin azalmasına, bütçe açıklarına ve harcama kalemlerinin değişmesine zemin hazırlamaktadır. Eğitim ve sağlık gibi beşeri sermaye birikimini doğrudan etkileyen harcamaların kapasitesini düşüren ve büyüme dinamizmini engelleyen bu süreç; politik istikrarsızlık ile başlamakta, sosyo-politik dengesizlik ile devam etmekte ve ekonomik sistemdeki yozlaşmaya bağlı olarak yolsuzluk ile nihai aşamaya ulaşmaktadır (Mauro, 1998).
Kamusal kesimin boyutlarının sorgulanması ışığında özgürlükçü bir piyasa yapılanmasına geçişin temelini hazırlayan politik istikrarsızlık ve nihayetinde beraberinde getirdiği yolsuzluk süreci birinci, ikinci ve üçüncü bölümde: Ekonomik Özgürlükler, Kamu Tercihi Teorisi ve Anayasal Politik İktisat ile Ordo Liberalizmi şeklinde üç temel argüman ile açıklanmaya çalışılmaktadır. Dördüncü bölümde konuyla ilgili bir literatür özeti sunulmuş, beşinci bölümde çalışmada kullanılan yöntem ve veriler üzerinde durulmuştur. Uygulama bulgularının yer aldığı altıncı bölüm ve sonuç bölümüyle çalışma tamamlanmıştır.

\section{EKONOMIK ÖZGÜRLÜKLER KAPSA- MINDA POLITIK ISTIKRAR}

Genel olarak ekonomik özgürlükler; gönüllü değişim ve serbest rekabet ile fikri ve mülkiyet haklarının güvence altına alındığı piyasa ekonomisinin mevcudiyetini ifade etmektedir. Bu mevcudiyet içindeki temel amaç, kurumsal yapılanma ile ekonomik politika bileşenlerinin karakterize edilmesidir. Temelini liberal düşünce yapısından alan ekonomik özgürlükler, kamusal müdahalelerin piyasalar üzerindeki etkilerinin minimum olması fikri üzerine inşa edilmiştir (Berggren, 2003). Bu bağlamda, liberal öğretinin en temel düşünce akımlarından birisini oluşturan ekonomik özgürlükler; serbest piyasa, özel girişim, gönüllü değişim, kapitalizm, sınırlı devlet, serbest ticaret, düşük vergi oranları, sermaye ile emeğin serbest hareketi ve bunun gibi ekonomik hayatın önemli unsurlarını oluşturan laissez faire - laissez passer felsefesi üzerine inşa edilmiştir. Dolayısıyla, bir ülkenin ekonomik ve politik bakımdan diğer bir ülkeye kıyasla daha fazla özgür olması, yukarıda da belirtilen liberal şartları taşıdığı anlamına gelmektedir (Rabushka, 1991).

Siyasal özgürlükler, uluslararası hukukun çeşitli araç ve prosedürleri aracılığıyla bireylere önemli yasal haklar sağlayan özgürlük göstergelerinden birisidir. Temel dayanakları İkinci Dünya Savaşı́nın sona ermesiyle atılan insan haklarının başlıca unsurlarından olan siyasal özgürlükler, bireysel hakların uluslararası platformda kabul edilen egemen formunu oluşturmuştur. Müktesebat gücünü Medeni ve Siyasi Haklara İlişkin Uluslararası Sözleşme (ICCPR)'den alan siyasal özgürlükler, Avrupa İnsan Hakları Sözleşmesi ile sahip olduğu uluslararası dayanağını pekiştirmiştir (Davis, 2000).

Literatürde siyasal teori iki kısım halinde incelenmektedir. Bunlardan ilki, politik etik ve ikincisi ise siyasal kurumlar teorisidir. Politik etik, siyasal faaliyetlerin aksamadan yerine getirilebilmesi için oluşturulan temel ilkeler bütünüdür. Siyasal hayatın düzenli işleyebilmesi amacıyla sahip olduğu temel ilkeleri, poli- 
tik kurumların yapısının anlaşılabilmesi için ana unsurları oluşturmaktadır (Raz, 1986). Adı geçen temel ilkeler ise siyasal haklar olarak karşımıza çıkmaktadır. Devletin özünü teşkil eden siyasal iktidar ile kamusal idarenin kuruluş ve işleyişi neticesinde bireylerin politik iktidara katılma gücünü ifade eden siyasal haklar, uluslararası hukuk prosedürü içerisinde dört başlık altında incelenmiştir. Bunlardan birincisi, siyasal hakların nüvesini oluşturan ve temel medeni haklar kategorisinde değerlendirilen ifade, temsil ve katılım hakkı gibi özgürlüklerin korunmasıdır. İkincisi, özellikle seçim yoluyla kamusal görev yönetimin etkin bir konuma gelme hakkının sağlanmasıdır. Üçüncüsü; sahip olunan siyasal hakların, toplumdaki diğer bireyler üzerinde baskı yaratması ile birlikte düşebilme yetisine olanak tanımasıdır. Dördüncü ve sonuncusu ise, uluslararası hukuki mevzuatta yer alan şekliyle politik hakların ayrımcılığa karşı olma özelliğini bünyesinde barındırmasıdır (Davis, 2000). Dolayısıyla, siyasal etiği oluşturan ilkeler, politik kurumların işleyişini kontrol etmesinin yanı sıra, bu kurumlara ulaşııması gereken hedefler de sunmaktadır. Siyasal etiğe ilaveten, siyasal teorinin ikinci kısmını oluşturan siyasal kurumlar ise devlet başta olmak üzere onun organlarını, daha geniş bir anlamda bütün kamusal otoriteyi ifade etmektedir. Tüm politik organizasyonların politik kurum olarak değerlendirilmemesi, politik kurumların yalnızca siyasal faaliyetlerde bulunan yapılanmalardan meydana geldiği gözden kaçırılmaması gereken bir noktayı vurgulamaktadır (Raz, 1986).

Beşeri olaylar döngüsünün en önemli tarihsel süreçlerinden bir tanesini oluşturan siyasal özgürlükler (Vatter, 2000) en genel ifadeyle toplumdaki baskı, zorlama ve cebir gibi unsurları ortadan kaldırabilmek ve demokratik sisteme toplumsal katılımcılığı sağlayabilmek amacıyla oluşturulmuş inançlar, tutumlar, davranışlar, değerler ve siyasal faaliyetlerde bulunan organize kurumlar bütünüdür (Brenkert, 1991). Siyasal özgürlüklerin temelinin atıldığı liberal görüşün çıkış noktasını "bireysel özgürlük" felsefesi oluşturmuş ve toplumsal bir varlık olan insanın doğuştan sahip olduğu özgürlüklerinin nasıl kurumsallaştırılacağı sorusuna cevap aranmıştır. Bu soru üzerinde mutabakata varılan temel yanıt, "ciddi bir politik sistem" olmuş ve bunun altyapısının neler olduğu araştırılmıştır (Ellul, 1976). Özgürlüğü, "bireyin, davranışlarında her türlü dış müdahale ve engellemeden bağımsız olması" biçiminde tanımlayan liberal öğreti, modern anlamda bireysel ve toplumsal özgürlüğü "özerklik" bağlamında somutlaştırabilen bir nüve haline getirmiştir. Bu somutlaşmanın tezahürü olarak da "yerel yönetimler" liberalizm içerisinde önemli bir siyasal birim işleviyle düşünülmüştür (Çelik ve Usta, 2010).
Bu görüşe ilaveten klasik liberalizm, sosyal sözleşme teorileri kapsamındaki özgürlük anlayışı nedeniyle devletin sınırlandırılması fikrini "anayasacılık" görüşü ile de pekiştirmiş ve bu çabasıyla da büyük bir destek almıştır. Özünü liberalizmden alan anayasacılık düşüncesi, devlet iktidarının birey haklarıyla sınırlandırılmasından oluşmuştur (Beaud, 2004).

Temelde siyasal gelişim süreci ile iktisadi dinamiklerin çoğunlukla birbirlerinden bağlantısız oldukları düşünülmüş; yani bireysel özgürlüklerin politik ve materyal refahın ise ekonomik bir problem olduğu savunulmuştur. Bu yanlış kanı; iktisadi düzenlemelerin, serbest bir toplumun oluşturulmasında oynadığı ikili yapının anlaşılması ile birlikte kırılmıştır. Bir taraftan iktisadi yapıda oluşturulan liberalizasyonun başlı başına bir özgürlük bileşeni olduğunun farkına varılmış ve diğer taraftan da yakalanan ekonomik özgürlüklerin politik liberalizmi gerçekleştirebilmek için zorunlu bir araç olduğu ortaya konmuştur. Siyasal özgürlüklere ulaşılmasında bir araç olarak düşünüldüguünde ise; ekonomik özgürlüklerin, gücün yayılmasında ya da merkezileştirilmesinde önemli etkilerinin olduğu belirlenmiştir. Rekabetçi kapitalizm gibi doğrudan ekonomik özgürlükleri sağlayan faaliyetlerin, iktisadi gücü politik güçten ayırmasına bağlı olarak siyasal özgürlükleri tesis edeceği öne sürülmüştür. Özellikle tarihsel süreç, siyasal özgürlükler ile piyasa mekanizması arasında güçlü bir bağın olduğunu göstermiş ve liberal bir politik yapıya sahip olan toplumların ekonomik özgürlüklerle sağlanmış olan serbest piyasa mekanizması yardımıyla bunu başarabildiklerini ortaya koymuştur (Friedman ve Friedman, 2002).

Her ülkenin kendi bünyesinde uyguladığı ekonomik faaliyetler siyasal gelenek üzerinde etkin bir rol oynamakta ve bu durum da kurumsal faktörler aracılığıyla gerçekleştirilmektedir. Adı geçen kurumsal faktörlerin önemi ise bütün ekonomik kararların altyapısının siyasal düzen içerisinde alınabileceğine dayanmaktadır. Güçlü bir siyasal altyapının da ancak ekonomik liberalizm ile sağlanabileceği ve tesis edilen politik etkinlik ile birlikte büyüme süreci için katalizör görevi yapabileceği bu kapsamda ifade edilmektedir (Farr vd., 1998). Bu sürece katkı sağlayan ve ekonomik bir değer taşıyan kurumlar ise, (a) kendi özel hakları kapsamında faydacı bir değere sahip olan beşeri özgürlük şartlarını sağlamaları ve (b) ekonomik faaliyetler yardımıyla bireylerin intiyaç duydukları gereksinimleri karşılamaları bakımından büyük bir önem taşımaktadırlar. "Kamu tercihi" ve "mülkiyet hakları" ekonomistlerinin de vurguladığı gibi, ekonomik özgürlükler ile birlikte ortaya çıkacak gelişmiş politik kurumlar yardımıyla siyasal haklar güçlendirilebilmekte ve böylece mülki hakların gelişmesine bağlı 
olarak piyasa mekanizmasının etkin işleyiş süreci hızlandırılabilmektedir (De Vanssay ve Spindler, 1994). Bu bağlamda, ekonomik liberalizmin politik istikrarın altyapısını ve bunun devamlılığını sağladığını söylemek mümkündür. Özellikle bürokratik engellerin ve kamusal müdahalelerin kaldırılmasına olanak tanıyan ekonomik özgürlükler, kârlı rant fırsatları ile siyasal gücün belirli ellerde toplanmasını engellemektedir. Genel bir ifadeyle, artan ekonomik özgürlüklerin piyasa mekanizmasının etkin işleyişini uyardığı ve bu durumun da yozlaşmış faaliyetlerin önüne geçerek siyasal özgürlükleri tesis ettiği söylenebilir (Goel ve Nelson, 2005). Elliott (1997) tarafından da ifade edildiği gibi, liberalize edilmiş ve reformlarla düzenlenmiş bir ekonomide piyasa mekanizmasındaki rekabet sistemi uyarılarak yolsuzluklar için rant fırsatları azaltılmakta ve bu sistem daha iyi yönetim kurumlarının tesis edildiği etkin bir politik yapının hazırlanmasına katkı sağlamaktadır (Akıncı, 2014).

Bireylerin; üretim, tüketim ve hayatını idame ettirme gibi seçim hürriyetlerini içeren ekonomik özgürlüklerini elde etmelerine paralel olarak kendi politik tercihleri doğrultusunda siyasal özgürlüklerini kazanabilme imkanları da ortaya çıkmaktadır. Bu bağlamda, bir ülkedeki ekonomik özgürlük sürecinin hızlanması ile birlikte siyasal özgürlüklerin de artan ivme kazanması kuvvetle muhtemeldir. İlaveten, siyasal özgürlüklerin gelişimi doğrultusunda ekonomik liberalizmin sağlanacağı yönünde bir düşünce akımı da gelişmiştir. Temelde yasal yapının varlığına dayanan bu akım, hukukun üstünlüğü ile adalet sisteminin gelişmesine bağlı olarak ortaya çıkan güven mekanizmasının oluşturacağı adil bir siyasal rejimin bireylere daha fazla seçim hakkı serbestisi tanıyarak piyasa mekanizmasını harekete geçireceği ve dolayısıyla da ekonomik liberalizmi güçlendireceği üzerine temellendirilmiştir (Gwartney ve Lawson, 2003). Bu bağlamda, her iki özgürlük türü arasında karşılıklı bir nedensel bağın olduğunu ifade eden görüşlerin de varlığının söz konusu olduğu söylenebilir.

Liberal bir piyasa yapısının varlığı ile siyasal özgürlükler arasındaki ilişki, politik hakların kullanılması ve kamusal otoriteye karşı korunması bakımından ekonomik özgürlüklerin gerekliliği üzerine de inşa edilmiştir. Özel mülkiyet sahipleri ile seçim hakkı varlığının devletin yetki alanını belirlediği ve böylece de hakların kullanımı önündeki engellemelere karşı bir güvence sağladığı vurgulanmıştır. Özellikle kolektivist bir ekonomik yapılanmada politik hakların tümüyle yasaklanacağının üzerinde durulmuş ve bu durumun da demokratik süreci ortadan kaldırarak etkin bir siyasal yapılanmayı engelleyeceği belirtilmiştir (Okun, 1975).

\section{KAMU TERCIHI VE ANAYASAL POLITIK IKTISAT KAPSAMINDA POLITIK ISTIKRAR}

"Politika biliminin ekonomik analizi" olarak tanımlanabilen Kamu Tercihi, politik süreçte alınan karar ve uygulamaları ekonomi biliminin kullandığı araç, metot ve varsayımlara dayalı olarak açıklayan bir disiplindir. Bu disiplin, kamu ekonomisinde karar alma mekanizmasının analizini yaparken üç temel varsayımdan yola çıkmaktadır. Bunlardan ilki, metodolojik bireyselcilik ilkesidir. Toplumda bütün ekonomik ve sosyal kararların birey tercihlerine göre belirlendiğini öne süren bu varsayım, devleti oluşturan organların aldığı kararların temelde birey tercihlerinin bir sonucu olduğunu vurgulamaktadır. İkincisi, rasyonalite ve maximand ilkesidir. Bu ilkeye göre bireyler, kamusal sistem içinde rasyonel ve kararlı tercihlere sahiptirler. Homo economicus özelliği sergileyen karar birimleri ve buradan hareket eden kamu tercihi, "kamusal çıkarın" ya da "toplumsal çıkarın" maksimize edilmesinin temel amaç olmadığını vurgulamaktadır. Siyasal karar alma sürecinde rol alan aktörlerin kendi çıkarlarını maksimize etmeye çalışmaları durumunda; (a) seçmenler için fayda maksimizasyonu, (b) siyasal partiler için oy maksimizasyonu, (c) bürokratlar için bütçe maksimizasyonu ve (d) çıkar ve baskı grupları için rant maksimizasyonu geçerli olmaktadır. Bu dört maksimizasyon olgusu maksimand ilkesi olarak adlandırılmaktadır. Üçüncü ve sonuncu varsayım olan politik mübadele ilkesi ise, siyasal karar alma mekanizmasının temelde politik süreçte rol alan bireyler arasındaki bir politik mübadele olduğu görüşünden hareket etmektedir. Bu bağlamda, kamusal ekonomik sistem içinde toplumsal isteklerin oluşumu politik mübadele süreci ile işlemektedir (Aktan, 2008).

Teorik Refah Ekonomisi, 1930 'lu ve 1940'lı yıllarda piyasa ekonomisinin milli ekonomi içinde başarısız ve yetersiz olduğunu, dolayısıyla devletin ekonomiye müdahale etmesi gerektiğini savunmuştur. 1960'। yıllardan itibaren ise kamu ekonomisinin tek başına optimumu sağlamaktan uzak olduğunu düşünen kamu tercihi iktisatçıları, devletin başarısızlığı teorisini geliştirmişlerdir. Devletin başarısızlığını çok sayıda faktöre bağlamakla birlikte üzerinde hassasiyetle durulan ortak noktayı "rant kollama faaliyetleri" oluşturmuştur. Yasama, yürütme ve yargı organları tarafından gerçekleştirilen faaliyetlerin baskı ve çıkar gruplarınca optimumdan uzaklaştırılacağını vurgulayan kamu tercihi teorisyenleri, ilgili grupların sahip oldukları seçim gücünü kullanarak lobicilik eylemlerine giriştiklerini ve sadece kendi çıkarları doğrultusunda devleti yönlendirdiklerini belirtmişlerdir. Kamu tercihi literatüründe "rant kollama" olarak adlandırılan bu faaliyetler, 
bir taraftan seçmen tercihini yansıtmayan sonuçlara yol açmakta ve diğer taraftan da ortaya çıkan politik istikrarsızlığa bağlı olarak yolsuzluklara yol açmaktadır (Yereli, 2003). Oy ve mali destek uğruna toplum ve ekonomik sistemdeki yerleşik kuralları ihlal edip etmediğini hiç önemsemeyen menfaat gruplarının emrine giren birçok politikacı, siyasi inançlarının temel değerlerinden vazgeçip hükümetin esas işlevine, yani evrensel kuralların ayrım gözetmeden uygulanması ilkesine ihanet etmektedir. Buchanan (1987) tarafından da vurgulandığı üzere, siyaset sahnesinde neler olduğunu anlamak için yüksek bilgi maliyetleriyle karşılaşan ve kolektif kararlar üzerinde çok az etkili olan vatandaşlar, parlamento ve bürokrasinin gelir ve refahın yeniden dağıtılması oyununda bilgisiz kalmaktadırlar. Kısır bir döngüye yönelen bu süreç, seçilmiş politikacılar ile atanmış bürokratların tekrar kendi çıkarları için hareket etmelerine olanak tanımaktadır. Dolayısıyla politik ters seçim; politik istikrarsızlık, yolsuzluk ve asil-vekil problemleri doğurmaktadır. Rant düzeyini yükseltebilmek amacıyla selektif müdahaleler arttığında rekabetçi piyasaların yapısı bozulmakta ve rekabetin genel yoğunluğu azalmaktadır. Piyasa sinyallerini anlamanın zorlaştığı bu yapılanmada ekonomik sistem, büyüme fırsatlarına ivme kazandıracak katalizör etkilerinin bir kısmını kaybetmektedir. Ekonomik gelişmeyi de sekteye uğratan olumsuz toplumsal ve iktisadi konjonktür, özgürlükçü sistemin tamamen tahribatıyla sonuçlanmaktadır (Kasper, 2007).

Kamu sektörünün büyümesiyle kendini gösteren ve politik istikrarsızık ile yolsuzluk bileşiminde var olan $X$ etkinsizliği', iki tür yozlaşmayı beraberinde getirmektedir. Bunlardan ilki olan ekonomik yozlaşma, artan politik istikrarsızlık ve yolsuzluk sürecine bağIı olarak kamu harcamalarında artışların olacağı savı üzerine kuruludur. Yolsuzluk dolayısıyla bozulan gelir dağılımını düzeltmek amacıyla devlet, gelir dağılımından yeterli pay alamayan kesimlere gelir transferi yapmak zorunda kalmaktadır. Bütçe açıklarının artmasına neden olan bu çözüm şekli, artan kamusal harcamalar nedeniyle yüksek enflasyona yol açmaktadır (Çoban, 1999). Artan kamu açıklarının borçlanma ya da emisyon ile karşılanmaya çalışııması durumunda enflasyonist baskılar kronikleşmekte ve yüksek bir faiz döngüsüne girilmektedir. Kredi maliyetlerinin artmasına ve yerli yatırımlar için dışlama etkisine neden olan bu durum dış piyasalara da sirayet ederek rekabetçi yapının bozulmasına, sürdürülemez boyutlardaki cari açık problemlerine, yüksek vergi oranlarına, artan ülke risklerine, daralan tasarruf ve yatırım kapasitesi nedeniyle düşük büyüme oranlarına ve özgürlükçü yapının kaybolduğu bir piyasa düzenine neden olmaktadır. Devletin ekonomik yaşamda artan fonksiyonunun ikinci sonucu, politik yozlaşma olarak karşımıza çıkmaktadır. Daha önce de vurgulandığı gibi, menfaat grupları-rant kollama-lobicilik eksenlerinde ortaya çıkan politik yozlaşma; rüşvet, nepotizm, kronizm, hizmet kayırmacıllğı, politik yandaşlık, lobicilik ve rant kollama faaliyetlerinin bütünü şeklinde meydana gelmektedir (Kuşat ve Dolmacl, 2011).

Temel olarak Buchanan tarafından yapılan çalışmalar ile altyapısı oluşturulan ve Hayek'in bilginin sınırları ile ekonomik yaşamın kurallarını incelediği düşünce sistematiğine dayanan Anayasal Politik Iktisat, en genel ifadesiyle "kuralların iktisadı" olarak tanımlanmaktadır. Tam bilgiye sahip olan rasyonel bireylerin oluşturduğu hipotetik dünyanın savunucusu Walrasyan geleneksel iktisadi düşüncenin yerini alan anayasal iktisat, sınırlı mental kapasite ve bilgiye sahip olan iktisadi ajanlardan oluşan aksak bir dünya ekonomisinin sınırlarından hareket etmektedir. Bu bağlamda anayasal iktisat, oyunun kurallarına daha iyi adapte olabilecek bireylerin sosyo-ekonomik ve politik düzenlemeler arasındaki ilişkileri nasıl geliştirebilecekleri noktasını incelemektedir. Buradan hareketle politik istikrarsızlık ve yolsuzluk süreçlerini kurallara bağlanmış politika yapımları ile açıklayan teori, toplum tarafından belirlenen genel kurallarla çerçevesi oluşturulan ve sosyoekonomik politika yapım süreçlerinin toplumsal yapı tarafından sınırlarının çizildiği bir kamu yapılanmasına kıyasla keyfi müdahaleciliğine dayanan hükümetlerde rant kollama faaliyetlerinin daha yoğun olacağını belirtmektedir. Her ne kadar anayasal kurallarla sınırlandırımış bir ekonomide yolsuzluklar tam olarak engellenemese de, yoğun bir ekonomik müdahaleciliğe bağlı yapılanmalar ile karşılaştırıldığında daha kesin sonuçlara ulaşılacağı ortak bir kanı haline gelmiştir (Vanberg, 2004).

Toplumda birlikte yaşayan bireylerin, temel hak ve özgürlükleri ile toplum içerisinde uyulması gerekli olan sınırları içeren informel kurallar üzerinde görüş birliğine varmalarını ifade eden ve "Sosyal Sözleşme" olarak betimlenen teoriye dayanan anayasal politik iktisat (Aktan, 2008), devletin ekonomik hak, yetki, görev ve sorumlulukları ile bireylerin ekonomik hak ve özgürlüklerini inceleme konusu yapmaktadır. Anayasal iktisatçılar, anayasalar hazırlanırken devletin yetkilerinin sınırlandırılmaması halinde ilerleyen dönemlerde devletin giderek büyüyeceğini, optimumu aşan yapılanmalara bağlı olarak politik sürecin istikrar kaybına uğrayacağını, ekonomik ve siyasal yapının giderek yozlaşacağını ve demokrasinin tahribe uğrayacağını savunmaktadırlar. Ancak, devletin hak ve yetkilerinin sınırlandırılması dolayısıyla bireylerin hak ve özgürlüklerine kavuşacakları ve yolsuzluklara kapalı bir iktisadi ortamın oluşacağı ifade edilmektedir (Yereli, 2003). 


\section{ORDO LIBERALIZMI KAPSAMINDA POLITIK ISTIKRAR}

Freiburg Okulu, liberalizme katkı sağlayan önemli bir kurum olarak bilinmektedir. Walter Eucken ve Franz Böhm'ün öncülüğünü yaptığı bir grup iktisatçı 1930'lu ve 1940 'lı yıllarda serbest piyasa ekonomisi içinde tam rekabet kurumunun bir ordro-naturel (doğal düzen) olarak kendiliğinden var olmayıp, bir ordro-social (sosyal düzen) olarak devlet tarafından organize edilmesi ve yasal önlemlerle korunması gerektiğini savunmuşlardır. İfade edilen iktisatçıların yanı sıra Freiburg Okulu'ndan diğer bazı iktisatçılar da görüşlerini ORDO başlığını taşıyan bir dergi kanalıyla yaymışlar ve böylece Ordo Liberalizmi adı verilen bir akım ortaya çıkmıştır (Aktan, 1995). Sosyal açıdan bir eşitliğin sağlanması amaç ve arzu edilmekle birlikte Ordo liberalleri aşırı müdahaleci devlet anlayışına karşı çıkmışlardır. Sınırlı ancak aktif ve düzenleyici devlet anlayışını savunan Ordo liberalizmi; özgürlük, rekabet ve sosyallik ilkeleri üzerine inşa edilerek, insan hak ve özgürlüklerinin korunduğu ve sosyal eşitlik ilkelerinin gözetildiği serbest bir piyasanın oluşması için teorik temeller oluşturmuştur. Dolayısıyla, Ordo liberalizminde devletin sosyal sorumluluğu da ön plana çıkmış, rekabetin etkin ve fonksiyonel bir şekilde işlemesi için devlete tamamlayıcılık görevi yüklenmiştir (Tayyar ve Çetin, 2013).

Ordo liberalizmi, laissez-faire ve klasik liberalizminin minimal ve sınırlı devlet anlayışını eleştirmektedir. Ordo'ya göre devlet; aktif, yapıcı, düzenleyici ve fonksiyonel olmalıdır. Devlet, oyunun kurallarını, bir diğer ifadeyle ekonomik düzenin hukuki çerçevesini oluşturmalıdır. Ayrıca devlet rekabete işlerlik kazandırmak için fonksiyonel bir rol üstlenmeli ve temel sosyal amaçları gerçekleştirmek için ekonomiye müdahale etmelidir. Bununla birlikte, dikkat edilmesi gereken temel nokta aşırı müdahaleci devlet anlayışının değil, sınırlı ve düzenleyici devlet anlayışııın ön plana çıkarıldığıdır. Bu bağlamda, politik istikrarın sağlanabilmesi için devlet gücünün tek bir elde toplanması yerine, yetki ile gücün paylaştııılması ve bu şekilde sınırlandırılması savunulmaktadır. Böylesi bir paylaşım ve sınırlandırma ise yatay ve dikey kuvvetler ayrılığ ${ }^{2}$ vasıtasıyla devlet gücünün herhangi bir menfaat kullanımından uzak tutulması ve gücün kötüye kullanılmasının engellenmesi için ön plana getirilmektedir (Aktan, 2008). Bununla birlikte Eucken, 19. yüzyıl sonlarında özel çıkar gruplarının baskısı altına giren kamu kurumlarının yozlaştığını ve devlet gücünün zayıfladığını vurgulamıştır. Ekonomik anayasacılığın, iktisadi ve siyasi yozlaşmalardan kurtulabilmek için en temel hareket noktası olduğunu savunan yazar, ekonomi kurumsallaşma yoluyla politik istikrarın ve yolsuzlukların önüne geçilebileceğini belirtmiştir (Jayasuriya, 2000).

\section{LITERATÜR ÖZETi}

Ekonomi literatüründe yolsuzluk olgusunu dikkate alan çok sayıda çalışma bulunmakla birlikte, bu çalışmaların odaklandığı temel faktörler yolsuzluğun belirleyicileri ile yolsuzluk-ekonomik büyüme ilişkisi olmuştur. Politik istikrarsızlık faktörü, yolsuzluğun belirleyicileri olarak sadece bir değişken şeklinde modelleme süreçlerinde kullanılmış, tek başına yaratabileceği etkiler ise genellikle inmal edilmiştir. Politik istikrar/istikrarsızlığın yolsuzluk üzerinde yarattığı etkileri inceleyen çok az sayıdaki çalışma ise, artan politik istikrarsızlık ile birlikte yolsuzlukların kendini göstereceği şeklindeki sonuçları ortaya koymuştur. Bu bağlamda, söz konusu bu çalışmanın literatüre doğrudan bir katkı yapacağı açıktır.

Yapmış olduğu teorik temelli çalışmasında, toplumsal yapının taleplerini uzun dönemde yerine getiremeyen hükümetlerin çıkar gruplarının baskısı altına gireceğini belirten Olson (1982), böylesi bir durumun uzun dönemli etkinlik ve büyüme hedefleri yerine çıkar gruplarının taleplerini karşılayacak politikalara zemin hazırladığının altını çizmiştir. Politik istikrarsızlığa doğru yönelimi hızlandıran bu sürecin yolsuzluk ile sonuçlanacağını ifade eden yazar, yatırım ve büyüme gibi makroekonomik faktörlerin de negatif yönlü olarak etkileneceğini ileri sürmüştür.

Yatay kesit analizlerini kullanarak 100 ülkede politik istikrarsızlığın ekonomik çıkarımlarını inceleyen Svensson (1998), istikrarsız bir politik sisteme sahip olan ülkelerde yasal sistemin etkinliğini kaybedeceğini ve mülkiyet haklarının güvence altına alınamayacağını, yurtiçi yatırım kapasitesinin düşeceğini, pazarlama kabiliyeti düşük olan ürünlerin üretileceğini, sermaye çıkışlarının yaşanacağını ve ekonomik sistemin artan yolsuzluklar ile mücadele etmek zorunda kalacağını belirtmiştir.

Treisman (2000), yolsuzluğun belirleyicilerini yatay kesit analizlerini kullanarak 1996-1998 yılları için 45 ülke itibariyle incelediği çalışmasında; Protestan geleneğe sahip, İngiliz hukuksal yapısı ile tarihsel köklere haiz, ekonomik bakımdan gelişmiş ve ithalat kabiliyeti yüksek olan ülkelerde yolsuzlukların daha az olduğunu ifade etmiştir. Bununla birlikte, federal eyaletlerin hüküm sürdüğü ülkelerde yoğun politik istikrarsızlıktan dolayı yolsuzlukların baskın olduğunu belirten yazar, cari dönem demokrasi düzeyinin yolsuzluk üzerinde anlamlı bir etkiye sahip olmadığını, ancak uzun dönemli demokrasinin ise yolsuzluğu azalttığını ifade etmiştir.

Montinola ve Jackman (2002), demokratik sürece yakınlık olarak belirttiği politik istikrar ile yolsuzluk arasındaki ilişkileri 66 ülkeyi dikkate alarak 1980-1983 
ve 1988-1992 dönemleri itibariyle panel veri analizleri kapsamında incelemişlerdir. Otokratik rejimlerle kıyaslandığında ılımlı bir demokrasi düzeyinin yolsuzluğu azaltmadığını belirten yazarlar, ancak belirli bir eşik değerinin aşılmasından sonra demokrasi ve dolayısıyla da politik istikrarın yolsuzluğunu engellediğini ifade etmişlerdir.

Ali ve Isse (2003), ekonomik özgürlüğün belirleyicilerini 83 ülke itibariyle 1975-1999 dönemini dikkate alarak panel veri analizleri yardımıyla inceledikleri çalışmalarında; hukuk sistemindeki etkinlik, yüksek okullaşma düzeyi, artan ekonomik özgürlükler, küçülen kamu kesimi, azalan yabancı yatırım seviyesi ve adem-i merkeziyetçi hükümet yapılanmalarının yolsuzluğu azalttığı sonucunu ortaya koymuşlardır. Bununla birlikte yazarlar; politik istikrar, politik özgürlük ve kişi başına düşen Gayri Safi Yurtiçi Hasıla (GSYiH)'nın yolsuzluğu negatif, ancak istatistiki bakımdan anlamsız etkilediğini de ifade etmişlerdir.

Politik yapılanmalar kapsamında değerlendirdikleri üniter ve federal sistemler ile parlamenter ve başkanlık sistemlerinin yolsuzluk üzerindeki etkilerini 125 ülke için panel veri analizleri kapsamında inceleyen Gerring ve Thacker (2004), üniter yapıdaki parlamenter hükümet sistemlerinin politik istikrarı artırmak suretiyle yolsuzluk düzeyini azaltmada önemli etkilerinin olduğunu göstermişlerdir.

Yolsuzluğun temel belirleyicilerinin ekonomik özgürlüklerden mi yoksa politik özgürlüklerden mi kaynaklandığı noktasından hareket ederek geniş bir ülke grubu itibariyle panel veri analiz tekniklerini kullanarak inceleyen Goel ve Nelson (2005), politik özgürlüklere kıyasla artan ekonomik özgürlük düzeyinin yolsuzlukları azaltmada daha etkin sonuçlar verdiği bulgusuna ulaşmışlardır. Bununla birlikte yazarlar, ekonomik özgürlük düzeyini oluşturan her bir faktörün yolsuzluğu azaltıcı etkisinin aynı oranda olmadığını belirterek, para politikasında yaratılacak özgürlükçü bir yapının maliye politikasına kıyasla yolsuzluğu önlemede daha başarılı olacağını da ifade etmişlerdir.

Politik faktörlerden hareket ederek yolsuzluğun belirleyicilerini geniş bir ülke grubu için 1984-1999 dönemi itibariyle panel veri analizlerini kullanarak araştıran Lederman vd. (2005); demokratikleşme düzeyi, parlamenter sistemler, politik istikrar ve basın özgürlüğü gibi faktörlerin düşük yolsuzluk düzeyine ulaşılmasında başlıca unsurlar olduğunu belirtmişlerdir.

Yolsuzluğun belirleyicilerini araştıran Serra (2006), 1997-1999 dönemini dikkate alarak 62 ülkeyi Küresel Hassasiyet Analizleri kapsamında incelemiştir. Demokratik kurumların hakim ve nüfusun büyük bir çoğunluğunun Protestan olduğu zengin ülkelerde yol- suzlukların oldukça düşük düzeyde olduğunu ortaya koyan yazar, politik istikrarsızlığın problem teşkil ettiği ülkelerde ise yolsuzlukların büyük boyutlara ulaştığını öne sürmüştür. Ayrıca yazar, kolonyal geçmişe sahip olan ülkelerde de yolsuzluk düzeyinin yüksek olma ihtimalinin de gözden kaçırılmaması gerektiği üzerinde durmuştur.

Campos ve Giovannoni (2007), 25 geçiş ülkesindeki 4000 firmayı dikkate alarak gerçekleştirdikleri panel veri analizlerinde lobicilik, yolsuzluk ve politik istikrar arasındaki ilişkileri incelemişlerdir. Lobicilik faaliyetleri ile yolsuzluğun birbirinin bir anlamda ikamesi olduğu; firma büyüklüğü, faaliyet yılı, mülkiyeti ve politik istikrarın lobi üyeliğinin en temel bileşenlerini oluşturduğu ve yolsuzluğa kıyasla lobi faaliyetlerinin politik sistem üzerinde daha etkin bir araç olduğu, ulaşılan en önemli sonuçlar olmuştur.

Yolsuzluğun belirleyicilerini ekonomik ve ekonomik olmayan faktörler bazında 41 gelişmekte olan ülke için panel veri analizleri kapsamında inceleyen Shabbir ve Anwar (2007), ekonomik faktör olarak değerlendirdiği ekonomik özgürlük, küreselleşme, eğitim düzeyi ve ortalama gelir seviyesinin yolsuzluk ile negatif ilişki içinde olduğu sonucuna ulaşmışlardır. Bununla birlikte yazarlar, yolsuzluğu açıklayabilmek için kullandıkları basın özgürlüğü, politik istikrar olarak tanımlanan demokrasi ve dini inançların anlamlı bir etki sergileyemediklerini de belirtmişlerdir.

Del Monte ve Papagni (2007), İtalya'nın bölgeleri arasında yolsuzluğun belirleyicilerini tespit edebilmek amacıyla 1963-2001 dönemini dikkate alarak panel veri analizlerini kullandıkları çalışmalarında, politik istikrar ve yolsuzluk arasındaki ilişkilerin $U$ şeklinde olduğunu belirterek, yetersiz politik rekabet, siyasi istikrarsızlık ve lobiciliğin yolsuzluğu artıran unsurlar olduğunu belirtmişlerdir.

Politik istikrar ve yolsuzluk arasındaki ilişkileri 136 ülkeyi dikkate alarak 1996-2005 dönemi için panel veri analizleri yardımıyla inceleyen Campante vd. (2008), ilgili değişkenler arasında U şeklindeki ilişkileri varlığını ortaya koymuşlardır. Politik süreçte istikrarın bozulmasına paralel olarak yolsuzlukların artacağını belirten yazarlar, yolsuzlukların azaltılmasında en azından ara sistemlerin oluşturulması gerekliliği üzerinde durarak, belirli bir zaman dilimi içinde yeniden seçilebilme teşviklerini bünyesinde barındıran bir seçim sisteminin yolsuzlukları minimum bir düzeye indirebileceğini de vurgulamışlardır.

Yolsuzluğun belirleyicilerini 99 ülkeyi dikkate alarak 2001-2003 dönemi için panel veri analizleri ile araştıran Billger ve Goel (2009); politik istikrar, ekonomik özgürlük ve kişi başına düşen GSYiH düzeyinin 
yolsuzluğu önlemede temel faktörler olduğunu göstermişlerdir. Ayrıca yazarlar, artan kentleşme düzeyinin yolsuzluk üzerinde negatif etkiler yarattığını da ortaya koymuşlardır.

Evrensel (2010), yolsuzluğun ekonomik ve kurumsal belirleyicilerini 154 gelişmiş ve gelişmekte olan ülke için 1998-2000 dönemi için yatay kesit analizleri yardımıyla incelediği çalışmasında; totaliter politik rejime, etkin olmayan adalet sistemlerine, düşük eğitim düzeyine, yetersiz ekonomik büyüme hızına ve yüksek enflasyon oranlarına sahip olan ülkelerde yolsuzlukların artma eğilimi içinde olduğu sonucuna ulaşmıştır.

Elbahnasawy ve Ravier (2012), yolsuzluğun belirleyicilerini çeşitli ülke grupları itibariyle panel veri analizlerini kullanarak araştırdıkları çalışmalarında; hukukun üstünlüğü, ekonomik büyüme, ifade özgürlüğü, kamu yönetimine katılma bağlamında fırsat eşitliği ve özgür bir medyanın olduğu ülkelerde yolsuzlukların azalacağı sonucuna ulaşmışlardır. Bununla birlikte yazarlar; doğal kaynak bolluğu, ülke nüfusunun büyüklüğü, ülkenin baskın dini özellikleri, etnik yapı ve politik istikrar değişkenlerinin ise yolsuzluğu açıklamada önemsiz faktörler olduğunu belirtmişlerdir.

Yolsuzluğun belirleyicilerini araştıran bir başka çalışmada Iwasaki ve Suzuki (2012), 202 ülkeyi dikkate alarak 1996-2006 dönemi için panel veri analizlerini kullandıkları çalışmalarında, politik istikrarın ve demokratik geçişin sağlanamadığı geçiş ülkeleri ile sosyalist ülkelerde yolsuzlukların büyük bir problem olarak devam ettiği sonucuna ulaşmışlardır. Ayrıca yazarlar, kişi başına düşen GSYiH düzeyi ile sanayi kesiminin GSYiH içindeki payının yolsuzluğu pozitif, federal yapılanmadaki hükümet sistemlerinin ise negatif olarak etkilediğini ortaya koymuşlardır.

Asongu (2013), 46 Afrika ülkesini dikkate alarak yolsuzluğun belirleyicilerini 2002-2008 dönemi itibariyle panel veri analizlerini kullanarak incelemiştir. Yazar tarafından elde edilen bulgular; demokratikleşme düzeyi, hesap verebilirlik, politik istikrar, kamusal etkinlik ve hukukun üstünlüğünün geçerli olduğu ülkelerde yolsuzluklarla optimum düzeyde savaşılabileceğini göstermiş̧tir.

Yolsuzluk, politik istikrarsızlık ve hukuki etkinsizlik arasındaki ilişkileri Pakistan ekonomisi için TodaYamamoto nedensellik analizi yardımıyla inceleyen Ismail ve Rashid (2013), yolsuzluk ve politik istikrarsızlık arasında doğrudan nedensellik ilişkilerinin geçerli olmadığını belirtmişlerdir. Ancak yazarlar, politik istikrarsızlık ile yolsuzluk arasındaki karşıııklı nedensellik ilişkilerinin sadece hukuksal etkinsizlik dolayısıyla ortaya çıktığını vurgulamışlardır.

\section{YÖNTEM VE VERILER}

Aşağıdaki grafikte dikey eksen politik hak ve özgürlüklere ait endeksi, yatay eksen ise yolsuzluk endeksini göstermektedir. Dikey eksendeki endeks büyüdükçe politik istikrarsızlık artmakta, yatay eksendeki endeks büyüdükçe yolsuzluklar azalmaktadır. Buna göre Danimarka yolsuzlukların az, politik istikrarın yüksek olduğu bir ülkedir. Grenada'da ise politik istikrar olmakla birlikte yolsuzluklar oldukça yüksektir. Singapur'da politik istikrar ortalamanın altında, yolsuzluklar ise düşük seviyededir. Çin'de politik istikrar oldukça önemli bir sorun teşkil etmekte iken, yolsuzluklar ise ortalamanın üzerindedir. Yunanistan ile Türkiye'nin politik istikrar ve yolsuzlukları karşılaştırılığında; Yunanistan politik istikrar bakımından Türkiye'den çok daha iyi durumda olmasına karşın, yolsuzluklar konusunda önemli bir farklılığın olmadığı görülmektedir.

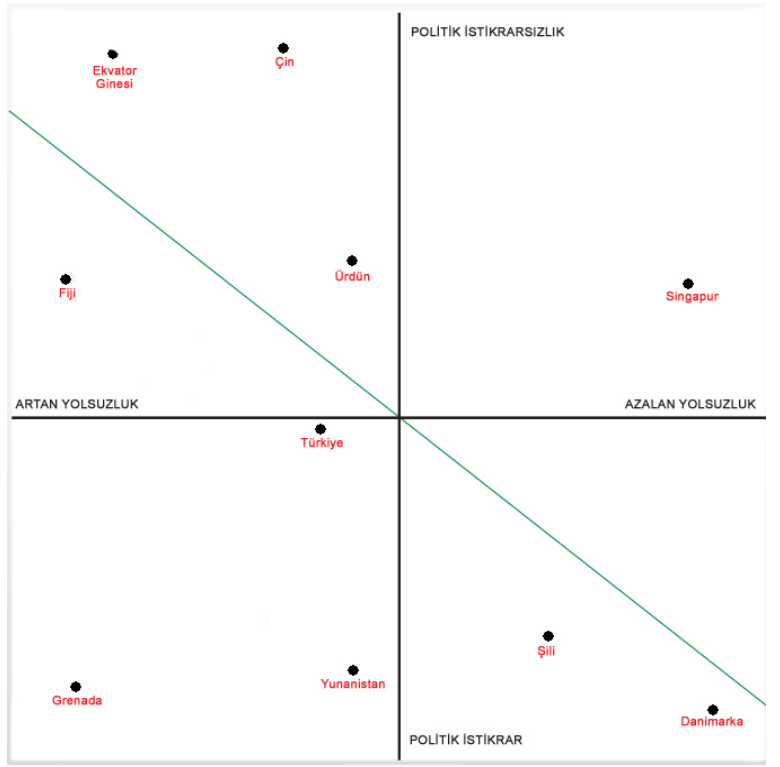

Şekil 1: Politik İstikrar ve Yolsuzluk illişkisi (1995-2013)

Çalışmada, politik hak ve özgürlükler ile yolsuzluklar arasındaki ilişkiler 31'i az gelişmiş, 91'i gelişmekte olan ve 51'i gelişmiş olan toplam 173 ülke için 19952013 dönemine ait yıllık veriler yardımıyla araştırılacaktır. Değişkenlere ait veriler Heritage Foundation ve Freedom House internet sitelerinden elde edilmiştir. Çalışmada panel veri yöntemleri kullanılacağından aşağıda öncelikle modelin genel bir tanıtımı yapılacak daha sonrada panel veri yöntemleri ile ilgili bilgiler kısaca sunulacaktır.

$\Delta$ Inyolsuzluk $_{\mathrm{it}}=\mathrm{a}_{\mathrm{it}}+\beta \Delta$ Inpolhak $_{\mathrm{it}}+\varepsilon_{\mathrm{it}}$

Burada:

Inyolsuzluk $_{\text {it }}=\mathrm{i}$ ülkesinde $\mathrm{t}$ dönemindeki logaritmik yolsuzlukları, 
Inpolhak $_{\mathrm{it}}=\mathrm{i}$ ülkesinde $\mathrm{t}$ dönemindeki logaritmik politik hak ve özgürlükleri,

$a_{i t}=$ Ülkeler arasındaki zaman farklılıklarını yansı$\tan$ sabit bir etkiyi,

$\varepsilon_{\text {it }}=$ Modelin kalıntılarını,

$\Delta=$ Fark işlemcisini temsil etmektedir.

Ekonomik bir ilişkinin belirlenmesinde model kapsamındaki diğer değişkenlerle ilişkili olabilen ve gözlenemeyen bireysel özel etkileri kontrol etme isteğini yansıtan panel veri analizleri 1980'li yıllardan itibaren artan bir ilgi görmektedir (Hausman ve Taylor, 1981). Panel veri analizinde birden fazla yatay kesit objesinin analiz dönemindeki gözlemleri kullanılarak regresyon yapılmakta ve bu nedenle de zaman serisi ile yatay kesit dalgalanmasına izin verilmektedir. Tipik bir panel veri analizinde bağımlı değişken için $N$ sayıda bireyin $T$ dönemlik zaman serisi verileri kullanılarak analiz yapılmaktadır. Genel anlamda panel veri denklemi aşağıdaki (2) numaralı eşitlik ile ifade edilmektedir (Kaya ve Yılmaz, 2006):

$$
\begin{array}{r}
Y_{i t}=\beta_{1 i t}+\beta_{2 i t} X_{2 i t}+\beta_{3 i t} X_{3 i t}+\varepsilon_{i t} \\
t=1 \ldots T \text { ve } i=1 \ldots N
\end{array}
$$

Panel veri analizinin en basit şekli, modelde yer alan katsayıların tüm yatay kesit bireyler için sabit tutulması durumudur ki bu varsayım aşağıdaki gibi bir denklemle gösterilmektedir:

$$
Y_{i t}=\beta_{1}+\beta_{2} X_{2 i t}+\beta_{3} X_{3 i t}+\varepsilon_{i t}
$$

(3) numaralı denklem; tüm bağımsız değişkenlerin, yatay kesit bireylerin hepsini aynı derecede etkilediğini öngörmektedir. Ancak bağımsız değişkenlerin, farklı bireyleri farklı şekilde etkilediğine inanılıyorsa bu denklem yetersiz kalmaktadır. Bu noktada ortaya çıkan temel konu başlangıç noktasının $\left(\beta_{1}\right)$ nasıl tanımlanacağıdır. Başlangıç noktası, tüm bireyler için sabit tutulabilir veya böyle bir kısıt konulmayarak farklı yatay kesit bireyler için farkıı başlangıç noktalarının olmasına izin verilebilir. Bu doğrultuda, başlangıç noktası tanımlaması için "sabit etkiler modeli" ve "tesadüfi etkiler modeli" olmak üzere iki alternatif yöntem bulunmaktadır. Panel veri analizlerinde, katsayıların birimlere ya da birimler ile zamana göre değiştiğinin varsayıldığı modellere "sabit etkiler modeli" denmektedir. Modelin genel formülasyonu; birimler arasındaki farklılıkların, sabit terimde meydana gelen farklılıklarla yakalanabileceği üzerine temellendirilmektedir. Dolayısıyla bu modellerde sadece sabit terim değişmekte ve sabit terim zamana göre değil, kesit bazında farklılıklar göstermektedir. Yani zaman boyutu sabit değişken tarafından muhafaza edilmesi- ne rağmen bireyler arasındaki davranışlarında farklılık göstermektedir (Pazarlıoğlu ve Gürler, 2007). Genel olarak sabit etkiler modeli aşağıdaki (4) numaralı eşitlik yardımıyla ifade edilmektedir (Judge, 1985):

$$
\begin{gathered}
y_{i t}=\bar{\beta}+\alpha_{i}+\beta_{1} X_{1 i t}+\ldots+\beta_{k} X_{k i t}+\varepsilon_{i t} \\
i=1,2, \ldots, G \text { ve } t=1,2, \ldots, N
\end{gathered}
$$

(4) numaralı eşitlikte $y_{i t}$, bağımlı değişkeni; $\bar{\beta}$, ortalama sabit terimi; $\alpha_{i}$, $i$ kesiti için ortalama sabit terimden farklıığı; $X_{i t}$, bağımsız değişkenleri; $i$ yatay kesit birimini; $t$, zamanı ve $\varepsilon_{i t}$ ise hata terimini göstermektedir. Bu eşitlikte yer alan hata terimi ile açıklayıcı değişkenler arasında bir ilişkinin söz konusu olması durumunda sabit etkiler modelinin kullanılması daha doğru olmaktadır. Çünkü bu durumda sabit etkiler modelinin tahmincileri sapmasız olmaktadır. Benzer şekilde, kesit sayısının az ve gözlem sayısının büyük olduğu durumlarda da sabit etkiler modelinin kullanılması uygundur.

Sabit etkiler modeline alternatif bir yaklaşım olarak geliştirilen tesadüfi etkiler modeli "hata bileşenleri yaklaşımı" şeklinde de ifade edilmektedir. Tesadüfi etkiler modelinde her bir kesit birimi için farklı trend değerlerinin söz konusu olduğu, bu trend değerlerinin zaman periyodu boyunca sabit kaldığı ve açıklanan ile açıklayıcı değişkenler arasında geçici bir yatay kesit ilişkisinin varlığı öne sürülmektedir. Bu bağlamda, tesadüfi etkiler modelinin temel farklılığı; bireysel yatay kesit birimi için geçerli olan trend değerlerinin, $\alpha$ gibi ortak bir trend değerinden kaynaklanıyor olması ve rassal değişimi yaratan $\varepsilon_{i}$ 'nin yatay kesitler boyunca değişip, belli bir dönem aralığında sabit kalmasıdır. Dolayısıyla $\varepsilon_{i}$, ortak trend terimi olan $\alpha$ 'dan hareketle hesaplanabilen her bir yatay kesit biriminin rassal sapmasını ölçmektedir (Brooks, 2008). Temel olarak tesadüfi etkiler modeli aşağıdaki gibi bir eşitlik yardımıyla ifade edilmektedir (Wooldridge, 2009):

$$
y_{i t}=\beta_{0}+\beta_{1} X_{1 i j}+\ldots+\beta_{k} X_{k i j}+\alpha_{i}+\varepsilon_{i t}
$$

Sabit etkiler modelinde bir veya birden fazla $X_{i j}$ ile ilişkili olduğu düşünüldüğünden dolayı $\alpha_{i}$, elimine edilmeye çalışıımaktadır. (5) numaralı tesadüfi etkiler modelinde ise tüm zaman periyodu boyunca her bir açıklayıcı değişken ile ilişkisiz olduğu varsayılmaktadır.

Panel veri analizlerinde değişkenler arasındaki uzun dönemli ya da eşbütünleşik ilişkiler de tespit edilebilmekte ve bu analizler için genellikle Pedroni ve Kao eşbütünleşme testlerinden yararlanılmaktadır. Pedroni (1999) tarafından geliştirilen eşbütünleşme testi aşağıdaki (6) numaralı panel regresyonundan 
hareketle ifade edilmektedir:

$$
y_{i t}=\alpha_{i t}+\delta_{i t} t+X_{i t} \beta_{i}+e_{i t}
$$

(6) numaralı eşitlikte yer alan $y_{i t}$ ve $X_{i t}$ sırasıyla $\left(N^{*} T\right) x 1$ ve $\left(N^{*} T\right) x m$ boyutundaki gözlemlenebilen değişkenleri vurgulamaktadır. Bu test, panel serilerinde eşbütünleşik bir ilişkinin olmadığını sınayan sıfır hipotezinin asimptotik ve sonlu gözlem özellikleri üzerine inşa edilmiştir. Hem uzun dönem eşbütünleşik vektörlerinde ve hem de dinamik modellerde panel seriyi oluşturan bireysel kesitler arasındaki heterojenliği ölçmeye olanak tanıyan bu eşbütünleşme analizi iki test grubundan oluşmaktadır. İlk grubu oluşturan testler, boyutlar-içi yaklaşım üzerine temellendirilmiş olup panel $v$-istatistiği, panel $\rho$-istatistiği, panel PP-istatistiği ve panel ADF-istatistiği olmak üzere dört testten oluşmaktadır. Bu istatistikler tahmin edilen kalıntı serileri üzerindeki birim kök testleri için farklı yatay kesit birimleri arasında otoregresif katsayıları birleştirmektedir. İkinci grubu oluşturan testler ise boyutlar-arası yaklaşım üzerine inşa edilmiştir ki toplamda üç testten meydana gelmektedir. Bunlar; grup $\rho$-istatistiği, grup PP-istatistiği ve grup ADFistatistiğidir. Bu istatistikler de her bir yatay kesit birimi için bireysel olarak tahmin edilen ortalama katsayı tahmincilerine dayanmaktadır (Lee, 2005).

Pedroni (1999) tarafından iki grup halinde ifade edilen test istatistikleri aşağıdaki eşitlikler yardımıyla hesaplanmaktadır (Pedroni, 1999):

Panel v-istatistiği:

$$
Z_{v}=\left(\sum_{i=1}^{N} \sum_{t=1}^{T} \hat{L}_{11 i}^{-2} \hat{e}_{i, t-1}^{2}\right)^{-1}
$$

Panel $\rho$-istatistiği:

$$
Z_{\rho}=\left(\sum_{i=1}^{N} \sum_{t=1}^{T} \hat{L}_{11 i}^{-2} \hat{e}_{i, t-1}^{2}\right)^{-1} \sum_{i=1}^{N} \sum_{t=1}^{T} \hat{L}_{11 i}^{-2}\left(\hat{e}_{i, t-1} \Delta \hat{e}_{i t}-\hat{\lambda}_{i}\right)
$$

Panel PP-istatistiği:

$Z_{t}=\left(\hat{\sigma}^{2} \sum_{i=1}^{N} \sum_{t=1}^{T} \hat{L}_{11 i}^{-2} \hat{e}_{i, t-1}^{2}\right)^{-1 / 2} \sum_{i=1}^{N} \sum_{t=1}^{T} \hat{L}_{11 i}^{-2}\left(\hat{e}_{i, t-1} \Delta \hat{e}_{i t}-\hat{\lambda}_{i}\right)$

Panel ADF-istatistiği:

$$
Z_{t}^{*}=\left(\hat{s}^{* 2} \sum_{i=1}^{N} \sum_{t=1}^{T} \hat{L}_{11 i}^{-2} \hat{e}_{i, t-1}^{* 2}\right)^{-1 / 2} \sum_{i=1}^{N} \sum_{t=1}^{T} \hat{L}_{11 i}^{-2} \hat{e}_{i, t-1}^{*} \Delta \hat{e}_{i t}^{*}
$$

Grup $\rho$-istatistiği:

$$
\tilde{Z}_{\rho}=\sum_{i=1}^{N}\left(\sum_{t=1}^{T} \hat{e}_{i, t-1}^{2}\right)^{-1} \sum_{t=1}^{T}\left(\hat{e}_{i, t-1} \Delta \hat{e}_{i t}-\hat{\lambda}_{i}\right)
$$

Grup PP-istatistiği:

$$
\tilde{Z}_{t}=\sum_{i=1}^{N}\left(\hat{\sigma}^{2} \sum_{i=1}^{T} \hat{e}_{i, t-1}^{2}\right)^{-1 / 2} \sum_{i=1}^{T}\left(\hat{e}_{i, t-1} \Delta \hat{e}_{i t}-\hat{\lambda}_{i}\right)
$$

Grup ADF-istatistiği:

$$
\tilde{Z}_{t}^{*}=\sum_{i=1}^{N}\left(\hat{s}_{i}^{2} \sum_{t=1}^{T} \hat{e}_{i, t-1}^{*^{2}}\right)^{-1 / 2} \sum_{t=1}^{T}\left(\hat{e}_{i, t-1}^{*} \Delta \hat{e}_{i t}^{*}\right)
$$

Bu eşitliklerde yer alan $\hat{e}_{i t}$, (6) numaralı denklemden elde edilen kalıntı değerlerini ve $\hat{L}_{11 i}^{2}$ ise $\Delta \hat{e}_{i t}$ için tahmin edilen uzun dönem kovaryans matrislerini ifade etmektedir. Benzer şekilde $\hat{\sigma}_{i}^{2}$ ve $\hat{s}_{i}^{2}\left(\hat{s}_{i}^{*^{2}}\right)$ ise sırasıyla bireysel $i$ için uzun dönem ve zamansal varyansları göstermektedir. Söz konusu bu yedi test asimptotik standart normal dağılım özelliklerini bünyesinde barındırmaktadır. Panel $v$-istatistiğinde elde edilen büyük pozitif değerler sonucunda eşbütünleşik ilişkinin olmadığını ifade eden sıfır hipotezi reddedilirken geri kalan diğer istatistiklerde ise yakalanan büyük negatif değerler sonucunda sıfır hipotezi reddedilebilmektedir.

Pedroni (1999) testinin aksine, kesikli ve homojen katsayılar özelinde bir sınamanın söz konusu olduğu Kao (1999) eşbütünleşme testi ise (14) numaralı panel regresyon modeline dayanmaktadır (Lau vd., 2011):

$$
y_{i t}=x_{i t}^{\prime} \beta+z_{i t}^{\prime} \gamma+\varepsilon_{i t}
$$

(14) numaralı eşitlikte $y_{i t}$ ve $x_{i t}$ 'nin I(1) seviyesinde durağan oldukları ve eşbütünleşik bir ilişkinin gerçekleşmediği varsayılmaktadır. $z_{i t}=\left\{\mu_{i}\right\}$ gibi bir eşitliği savunan Kao (1999), $\varepsilon_{i t}$ serisi için yapılacak DF ve ADF birim kök testlerinden hareketle seriler arasındaki eşbütünleşme ilişkisini araştırmıştır. DF serisinin $\hat{\varepsilon}_{i t}=\rho \hat{\varepsilon}_{i, t-1}+v_{i t}$ ve ADF serisinin ise $\hat{\varepsilon}_{i t}=\rho \hat{\varepsilon}_{i, t-1}+\sum_{j=1}^{p} \varphi_{j} \Delta \hat{\varepsilon}_{i, t-j}+v_{i t p} \quad$ eşitlikleri yardmıyla hesaplandığı kalıplarda $\hat{\varepsilon}_{i t}=\tilde{y}_{\hat{i t}}-\tilde{x}_{i t} \hat{\beta}$ ve $\tilde{y}=y_{i t}-\bar{y}_{i}$ olmaktadır. Bu kalıplardan hareketle $\rho$ ve $t$ istatistiklerinin EKK tahminleri,

$$
\hat{\rho}=\frac{\sum_{i=1}^{N} \sum_{t=2}^{T} \hat{\varepsilon}_{i t} \hat{\varepsilon}_{i, t-1}}{\sum_{i=1}^{N} \sum_{t=2}^{T} \hat{\varepsilon}_{i t}^{2}} \text { ve } t_{\rho}=\frac{(\hat{\rho}-1) \sqrt{\sum_{i=1}^{N} \sum_{t=2}^{T} \hat{\varepsilon}_{i, t-1}^{2}}}{S_{e}}
$$


denklemleri yardımıyla hesaplanmaktadır. Seriler arasında eşbütünleşik bir ilişkinin olmadığının varsayıldığı sıfır hipotezi altında Kao (1999) tarafından hesaplanan DF ve ADF istatistikleri aşağıdaki eşitlikler yardımıyla hesaplanmaktadır:

$$
\begin{aligned}
& D F_{\rho}=\frac{\sqrt{N} T(\hat{\rho}-1)+3 \sqrt{N}}{\sqrt{51 / 5}} \\
& D F_{t}=\sqrt{\frac{5 t_{\rho}}{4}}+\sqrt{\frac{15 N}{8}} \\
& D F_{\rho}^{*}=\frac{\sqrt{N T}(\hat{\rho}-1)+\frac{3 \sqrt{N} \hat{\sigma}_{v}^{2}}{\hat{\sigma}_{0 v}^{2}}}{\sqrt{3+\frac{36 \hat{\sigma}_{v}^{4}}{5 \hat{\sigma}_{0 v}^{4}}}} \\
& D F_{t}^{*}=\frac{t_{\rho}+\frac{\sqrt{6 N} \hat{\sigma}_{v}}{2 \hat{\sigma}_{0 v}}}{\sqrt{\frac{\hat{\sigma}_{0 v}^{2}}{2 \hat{\sigma}_{v}^{2}}+\frac{3 \hat{\sigma}_{v}^{2}}{10 \hat{\sigma}_{0 v}^{2}}}} \\
& A D F=\frac{t_{A D F}+\frac{\sqrt{6 N} \hat{\sigma}_{v}}{2 \hat{\sigma}_{0 v}}}{\sqrt{\frac{\hat{\sigma}_{0 v}^{2}}{2 \hat{\sigma}_{v}^{2}}+\frac{3 \hat{\sigma}_{v}^{2}}{10 \hat{\sigma}_{0 v}^{2}}}}
\end{aligned}
$$

Bu denklemlerde $\hat{\sigma}_{v}^{2}=\hat{\Sigma} y y-\hat{\Sigma} y x \hat{\Sigma}^{-1} x x$ ve $\hat{\sigma}_{0 v}^{2}=\hat{\Omega} y y-\hat{\Omega} y x \hat{\Omega}^{-1} x x$ 'dir. $\quad t_{A D F} \quad$ değeri ise $\hat{\varepsilon}_{i t}=\rho \hat{\varepsilon}_{i, t-1}+\sum_{j=1}^{T} \varphi_{j} \Delta \hat{\varepsilon}_{i, t-j}+v_{i t p} \quad$ eşitliğindeki $\rho$ 'nun $t$ istatistiğini vurgulamaktadır.

Eşbütünleşme analizlerini takiben değişkenler arasındaki sebep-sonuç ilişkileri literatüre ilk kez Granger $(1964,1969)$ tarafından kazandırılan ve daha sonra ise Hamilton (1994) tarafından geliştirilen nedensellik analizleri yardımıyla incelenmiştir. Granger nedenselliğinde $X$ ve $Y$ gibi iki değişken arasındaki ilişkinin yönü araştırılır. Eğer mevcut $Y$ değeri, $X$ değişkenin şimdiki değerinden çok geçmiş dönem değerleri ile daha iyi tahmin edilebiliyorsa $X$ değişkeninden $Y$ değişkenine doğru bir Granger nedenselliğinden söz edilebilir (Charemza ve Deadman, 1993). İki değişken arasında "sebep olma ilişkisi" araştırılırken (21) ve (22) numaralı kalıplar uygulanır (Kutlar, 2007):

$$
\begin{aligned}
& Y_{i t}=\sum_{i=1}^{n} \alpha_{i t} Y_{i, t-k}+\sum_{i=1}^{n} \beta_{i t} X_{i, t-k}+E C_{i t-1}+u_{1 i t} \\
& X_{i t}=\sum_{i=1}^{n} \alpha_{i t} X_{i, t-k}+\sum_{i=1}^{n} \beta_{i t} Y_{i, t-k}+E C_{i t-1}+u_{2 i t}
\end{aligned}
$$

Burada $u_{1 i, t}$ ve $u_{2 i, t}$ hata terimlerinin ilişkisiz oldukları varsayılmaktadır. Böylece (21) ve (22) numaralı denklemler değişkenlerin geçmiş değerlerine bağlı olduğu kadar kendi geçmiş değerlerinin de bir fonksiyonudur. Granger nedenselliğinde; $Y_{i t}$ ile $X_{i t}$ arasında tek ve çift yönlü bir nedensellik ilişkisi olabileceği gibi değişkenler arasında herhangi bir nedensellik ilişkisinin söz konusu olmadığı durum da ortaya çıkabilir.

\section{UYGULAMA BULGULARI}

$\mathrm{Bu}$ bölümde, panel veri analizlerinde uygulama çerçevesinde panel birim kök testleri, panel eşbütünleşme testleri, Granger nedensellik testleri, birim ve zaman etkilerini gösteren $F$ ve $L M$ testleri ve sabit etkili model tahmin sonuçları gösterilecektir. Çalışmada kullanılan değişkenlerin yatay kesit ba-

\begin{tabular}{|c|c|c|c|c|c|}
\hline \multirow{2}{*}{$\begin{array}{l}\text { Değiş- } \\
\text { kenler }\end{array}$} & \multirow{2}{*}{ Test Adı } & \multicolumn{2}{|c|}{ Seviye Değeri } & \multicolumn{2}{|c|}{ 1. Fark Değeri } \\
\hline & & $\begin{array}{c}\text { Test } \\
\text { istatistiği }\end{array}$ & Olasılık & $\begin{array}{c}\text { Test } \\
\text { istatistiği }\end{array}$ & Olasılık \\
\hline \multirow{4}{*}{ Yolsuzluk } & $\begin{array}{l}\text { ADF - Fisher } X^{2} \\
\text { Testi }\end{array}$ & 222.8590 & 1.0000 & $2067.2200^{*}$ & 0.0000 \\
\hline & $\begin{array}{l}\text { ADF - Choi Z İs- } \\
\text { tatistiği }\end{array}$ & 5.4308 & 1.0000 & $-35.0915^{*}$ & 0.0000 \\
\hline & $\begin{array}{l}\text { PP - Fisher } X^{2} \\
\text { Testi }\end{array}$ & 251.7890 & 0.9999 & $2174.83^{*}$ & 0.0000 \\
\hline & $\begin{array}{l}\text { PP - Choi Z İsta- } \\
\text { tistiği }\end{array}$ & 5.6436 & 1.0000 & $-36.5371^{*}$ & 0.0000 \\
\hline \multirow{4}{*}{$\begin{array}{l}\text { Politik } \\
\text { Hak ve } \\
\text { Özgür- } \\
\text { lükler }\end{array}$} & $\begin{array}{l}\text { ADF - Fisher } X^{2} \\
\text { Testi }\end{array}$ & 208.9470 & 0.4685 & $1654.4700^{*}$ & 0.0000 \\
\hline & $\begin{array}{l}\text { ADF - Choi Z Is- } \\
\text { tatistiği }\end{array}$ & -0.0623 & 0.4752 & $-34.1322^{*}$ & 0.0000 \\
\hline & $\begin{array}{l}\text { PP - Fisher } X^{2} \\
\text { Testi }\end{array}$ & $277.6630^{*}$ & 0.0137 & $1865.8300^{*}$ & 0.0000 \\
\hline & $\begin{array}{l}\text { PP - Choi Z İsta- } \\
\text { tistiği }\end{array}$ & -1.4208 & 0.0777 & $-36.5786^{*}$ & 0.0000 \\
\hline
\end{tabular}
ğımlı olup olmadıklarını araştırmak için Pearson LM Normallik testi uygulanmış ve Pearson LM istatistiği (0.0001) olarak bulunmuştur. Dolayısıyla değişkenlerin yatay kesit bağımsız oldukları kabul edilmiştir. Bu nedenle birinci nesil birim kök testleri uygulanmıştır.

Tablo 1: Panel Birim Kök Test Sonuçları

Not: ADF-Fisher ve PP-Fisher $x^{2}$ testleri asimtotik $x^{2}$ dağılımı, ADFChoi ve PP-Choi $Z$ İstatistikleri ise asimtotik normal dağılım göstermektedir. "işareti ilgili değişkenin \%1 önem düzeyinde durağan olduğunu yansıtmaktadır. İstatistikler hesaplanırken optimum gecikme uzunluğunun belirlenmesinde SIC kriterinden yararlanılmış̦ı. Ayrıca PP-Fisher istatistik değerleri hesaplanırken hem Barlett Kerneli ve hem de Newey-West bant genişlik kriterlerinden yararlanılmıştır. 
Tablo 1, modelde dikkate alınan değişkenlere ilişkin birim kök test bulgularını göstermektedir. Birim kök testi sonuçları, dört farklı durağanlık testi için dikkate alınan değişkenlerden sadece politik hak ve özgürlükler değişkeni PP - Fisher $X^{2}$ testinde seviye değerinde durağan çıkarken diğer bütün testlerde her iki değişken de 1 . fark değerlerinde durağan çıkmışlardır. Modelde dikkate alınan değişkenler arasında yatay kesit bağımlılığı bulunmadığından uzun dönemli ilişkilerin tespit edilebilmesi için Pedroni ve Kao eş-bütünleşme testlerinden yararlanılmıştır.

Tablo 2: Pedroni ve Kao Eş-Bütünleşme Test Sonuçları

\begin{tabular}{|c|c|c|c|c|}
\hline \multicolumn{5}{|c|}{ Pedroni Eş-Bütünleşme Testi } \\
\hline Testin Adı & Test İstatistiği & Olasılık & $\begin{array}{l}\text { Ağırlık- } \\
\text { landırıl- } \\
\text { mış } \\
\text { Test İsta- } \\
\text { tistiği }\end{array}$ & Olasılık \\
\hline Panel v İstatistiği & -44.0295 & 1.0000 & $1.2476^{* * *}$ & 0.1061 \\
\hline Panel rho İstatistiği & $-4.3423^{*}$ & 0.0000 & $-2.8503^{*}$ & 0.0022 \\
\hline Panel PP İstatistiği & $-8.1465^{*}$ & 0.0000 & $-5.1477^{*}$ & 0.0000 \\
\hline Panel ADF İstatistiği & $-5.5079^{*}$ & 0.0000 & $-5.9842^{*}$ & 0.0000 \\
\hline Grup rho İstatistiği & 1.3665 & 0.9141 & - & - \\
\hline Grup PP İstatistiği & $-5.6414^{*}$ & 0.0000 & - & - \\
\hline Grup ADF İstatistiği & $-6.5726^{*}$ & 0.0000 & - & - \\
\hline $\begin{array}{l}\text { Kao Eş-Bütünleşme } \\
\text { Testi }\end{array}$ & \multicolumn{4}{|c|}{$\begin{array}{cc}\text { t İstatistiği } & \text { Olasılık } \\
-6.3541^{*} & 0.0000\end{array}$} \\
\hline
\end{tabular}

Not: Eşbütünleşme ilişkisinin belirlenebilmesi için kullanılan her iki testte de Bartlett Kerneli ve Newey-West bant genişlik kriterlerinden yararlanılmıştır. Değişkenlere ilişkin optimum gecikme uzunluklarının hesaplanmasında SIC kriteri esas alınmıştır. ", "** ve ${ }^{* * *}$ işaretleri ilgili istatistik değerlerinin sırasıyla \%1, \%5 ve \%10 önem düzeyinde anlamlı olduklarını yansıtmaktadır.

Gerek Tablo 2'deki Pedroni ve Kao panel eşbütünleşme test sonuçları gerekse de Tablo 3'deki Johansen-Fisher panel eş-bütünleşme test sonuçları çaIışmada incelenen değişkenler arasında eş-bütünleşik yani uzun dönemli ilişkilerin geçerli olduğu sonucunu ortaya koymuştur. Uzun dönemli ilişkilerin elde edilmesi değişkenler arasında en azından tek yönlü bir nedensellik ilişkisinin geçerli olmasının beklendiğini yansıtmaktadır.

Tablo 3: Johansen-Fisher Panel Eş-Bütünleşme Test Sonuçları

\begin{tabular}{|l|c|c|c|c|}
\hline \multirow{2}{*}{$\begin{array}{c}\text { Eş-Bütünleşme } \\
\text { Vektörü }\end{array}$} & \multicolumn{2}{|c|}{ Trace Test İstatistiği } & \multicolumn{2}{c|}{$\begin{array}{c}\text { Max. Eigenvalue Test } \\
\text { İstatistiği }\end{array}$} \\
\cline { 2 - 5 } & İstatistik & Olasılık & İstatistik & Olasılık \\
\hline Hiç Yok & $470.80^{*}$ & 0.0000 & $406.50^{*}$ & 0.0000 \\
\hline En Az Bir Tane & $291.20^{*}$ & 0.0000 & $291.20^{*}$ & 0.0000 \\
\hline
\end{tabular}

Not: Değişkenlere ilişkin optimum gecikme uzunluklarının hesaplanmasında SIC kriteri esas alınmıştır. " işareti ilgili istatistik değerinin \%1 önem düzeyinde anlamlı olduğunu yansıtmaktadır.

Tablo 4, Granger nedensellik test sonuçlarını göstermektedir. Buna göre çalışmaya dahil edilen yüz yetmiş üç ülkede politik hak ve özgürlüklerden yolsuzluklara doğru bir nedensel etkinin olduğu görülmüştür. Tablodan da görüleceği gibi politik hak ve özgürlükler değişkeninden yolsuzluk değişkenine doğru \%5 önem düzeyinde bir Granger nedenselliği vardır. Oysa yolsuzluklardan politik hak ve özgürlüklere yönelik bir nedensel ilişki bulunamamıştır. Diğer bir ifadeyle yolsuzluklardan politik hak ve özgürlüklere yönelik bir ilişki olmadığı yönündeki hipotez reddedilememiştir. Eşbütünleşik denklem aşağıdaki gibi tahmin edilmiştir:

$$
\begin{aligned}
& \text { Inyolsuzluk }_{\mathrm{it}}=1.470-0.591 \text { Inpolhak }_{\mathrm{it}} \\
& \text { s.h. } \quad:(0.075)(0.006)
\end{aligned}
$$

Eşbütünleşme denklemi tahmin sonuçlarına göre, politik istikrardaki \% 1'lik bir artış yolsuzluklarda \% 0.591 'lik bir azalmaya neden olmaktadır.

\begin{tabular}{|c|c|c|c|}
\hline Değişken Adı & $\begin{array}{c}\text { Nedenselliğin } \\
\text { Yönü }\end{array}$ & F İstatistiği & Olasilık \\
\hline$\Delta$ Inpolhak- $\Delta$ Inyolsuzluk & $\rightarrow$ & $3.8272^{* * *}$ & 0.0506 \\
\hline$\Delta$ Inyolsuzluk- $\Delta$ Inpolhak & - & 0.0679 & 0.7944 \\
\hline
\end{tabular}

Tablo 4: Granger Nedensellik Test Sonuçları

Not: Parantez içindeki değerler, AIC ve SIC kriterleri kullanılarak hesaplanan optimum gecikme uzunluklarını yansıtmaktadır. " işareti ilgili istatistik değerinin sırasıyla \%5 önem düzeyinde anlamlı olduğunu yansıtmaktadır.

Değişkenler arasındaki nedensellik ilişkilerinin belirlenmesini takiben çalışmanın bu aşamasında sabit ve tesadüfi etkili modeller tahmin edilmeye çalışılmıştır. Bu amaç doğrultusunda uygun panel veri modeline karar verilebilmesi için birim ve zaman etkilerini gösteren F ve LM testleri yapılmıştır. Tablo 5, F ve LM test sonuçlarını göstermektedir. Tabloya göre gerek $F$ gerekse LM testinde zaman etkileri \%1 önem düzeyinde anlamlı bulunmuşken birim etkileri anlamsızdır. Ayrıca Hausman testi sonucu \%1 önem düzeyinde sabit etkili modelin kullanılmasının gerekli olduğunu göstermektedir.

Tablo 5: Birim ve Zaman Etkilerini Gösteren F ve LM Test

\begin{tabular}{|c|c|c|c|c|c|}
\hline \multirow{2}{*}{ İlişki } & \multicolumn{2}{|c|}{ F Testi } & \multicolumn{2}{|c|}{ LM Testi } & \multirow{2}{*}{$\begin{array}{l}\text { Haus- } \\
\text { man } \\
\text { Testi }\end{array}$} \\
\hline & Test & İstatistik & Test & İstatistik & \\
\hline $\begin{array}{c}\text { Yolsuzluklar } \\
\text { ve Politik } \\
\text { Haklar }\end{array}$ & $\begin{array}{l}\text { F Birim } \\
\text { F Zaman } \\
\text { FBirim- } \\
\text { Zaman }\end{array}$ & $\begin{array}{l}0.9493 \\
8.1058^{*} \\
1.6009^{*}\end{array}$ & $\begin{array}{l}\text { F Birim } \\
\text { F Zaman } \\
\text { FBirim- } \\
\text { Zaman }\end{array}$ & $\begin{array}{l}100.8888^{*} \\
2.3935^{*} \\
73.0317^{*}\end{array}$ & $109.0823^{*}$ \\
\hline
\end{tabular}
Sonuçları

Not: ${ }^{*},{ }^{* *}$ ve ${ }^{* * *}$ işaretleri ilgili istatistik değerlerinin sırasıyla $\% 1, \% 5$ ve \%10 önem düzeyinde anlamlı olduklarını yansıtmaktadır.

Birim ve zaman etkilerinin tespit edilmesini takiben modelde dikkate alınan değişkenler arasındaki ilişkileri belirleyebilmek amacıyla sabit etkili model tahmin edilmiş ve analiz sonuçları Tablo 6'da sunulmuştur. Sabit etkili model tahmin sonuçları politik 
hak ve özgürlüklerin yolsuzluklar üzerinde beklenildiği gibi negatif işaretli ve anlamlı etkilerinin olduğunu göstermiştir. Bu sonuç Granger nedensellik testi ile de uyuşmaktadır. Ancak okuyucu buradaki sonuçları yorumlarken bir hususa özellikle dikkat etmelidir. Zira politik hak ve özgürlükleri temsil eden endeks ile yolsuzlukları temsil eden endeksin yorumlanması birbirinin tam tersidir. Politik hak ve özgürlüklere yönelik endeksin düşmesi o ülkede özgürlüklerin arttığının bir göstergesi iken, yolsuzluk endeksinin yükselmesi ise yolsuzlukların azaldığını göstermektedir. Sabit etkili model tahmin sonuçlarına göre politik hak ve özgürlükler endeksinde meydana gelecek \%1'lik bir artış yolsuzluk endeksinde \%0,0603'lük bir azalma meydana getirmektedir. Dolayısıyla 1995-2013 döneminde ele alınan 173 ülkede politik istikrarsızlığın artması yolsuzlukları artırmaktadır. Eş-bütünleşik ilişkiden dolayı modele dahil edilen hata düzeltme parametresini gösteren EC'nin beklentileri karşılar nitelikte negatif ve istatistiki olarak \%1 önem düzeyinde anlamlı çıkması ortaya çıkabilecek olan kısa dönemli dengesizliklerin uzun dönemde giderilebileceğini göstermektedir.

Tablo 6: Sabit Etkili Model Tahmin Sonuçları

\begin{tabular}{|c|c|c|c|}
\hline Değişken Adı & Katsayı & t İstatistiği & Olasılık \\
\hline C & $0.0082^{*}$ & 3.6733 & 0.0002 \\
\hline$\Delta$ Inpolhak & $-0.0603^{*}$ & -3.2218 & 0.0013 \\
\hline EC(-1) & $-0.2965^{*}$ & -19.1345 & 0.0000 \\
\hline Birim Etkisi: Yok & Zaman Etkisi: Var \\
\hline $\mathbf{R}^{\mathbf{2}}=\mathbf{0 . 2 7 2 8} \quad \mathbf{F}=\mathbf{3 . 8 1 1 5 ^ { * }} \quad$ DW=1.7733 & $\mathbf{F}_{\text {olasıllk }} \mathbf{= 0 . 0 0 0 0}$ \\
\hline
\end{tabular}

Not: Değişkenler arasında eşbütünleşik bir ilişki elde edildiğinden modellere hata düzeltme parametresi eklenmiş ve EC(-1) olarak adlandırılmıştır. * işareti ilgili istatistik değerinin \%1önem düzeyinde anlamlı olduğunu yansıtmaktadır.

\section{SONUÇ}

Çalışmada, 1995-2013 döneminde 31'i az gelişmiş, 91'i gelişmekte olan ve 51'i gelişmiş olmak üzere toplam 173 ülke için, politik istikrarsızlık ile yolsuzluklar arasında bir ilişkinin var olup olmadığı varsa bu ilişkinin yönü panel veri analizleri yardımıyla incelenmiştir.

Değişkenlere uygulanan panel birim kök testleri sonucunda her iki değişkenin de birinci fark değerlerinde durağan olduğu tespit edilmiştir. Daha sonra Pedroni ve Kao panel eş-bütünleşme testi ve Johansen-Fisher panel eş-bütünleşme testi uygulanmış ve incelenen değişkenler arasında her üç test sonuçlarına göre uzun dönemli ilişkinin olduğu sonucuna varılmıştır. Bu sonuçlar neticesinde, değişkenler arasında en azından tek yönlü bir nedensellik ilişkisi olabileceği düşüncesiyle çalışmaya dahil edilen 173 ülke için Granger nedensellik analizi yapılmış ve politik hak ve özgürlüklerden yolsuzluklara doğru tek yönlü nedensellik ilişkisi tespit edilmiştir. Granger nedensellik testine benzer şekilde, dikkate alınan ülkelere uygulanan sabit etkili modelin tahmin sonuçlarına göre de politik hak ve özgürlüklerin yolsuzluklar üzerinde beklenildiği gibi ters yönlü ve anlamlı bir etkiye sahip olduğu görülmüştür. Ele alınan ülkelerde politik hak ve özgürlük endekisindeki yüzde 1'lik bir artış yolsuzluk endekisinde yüzde 0,0603'lük bir düşüş meydana getirmektedir. Sonuç olarak, ele alınan 173 ülkede, 1995-2013 döneminde politik istikrarsızlığın artması yolsuzlukları artırmaktadır.

Dünya genelinde yolsuzlukların birçok nedeni olabilmektedir. Özellikle politik istikrarsızlıklar, sıkça yaşanan hükümet değişiklikleri ve siyasi partilerin gelir ve harcamalarının kontrol edilememesi gibi nedenlerden yolsuzlukların arttığı bilinen bir gerçektir. Bu nedenle politik istikrarın sağlanması hem ekonomik istikrarın sağlanmasında hem de yolsuzlukların önlenmesinde hayati bir öneme sahiptir. Politik istikrarsızık neticesinde ortaya çıkan popülist politikalar kayıt dışı ekonominin büyümesine neden olarak, vergi kaçakçılığı rüşvet ve yolsuzluğun artmasına sebebiyet verebilmektedir. Politik istikrarsızlık ile birlikte kendini gösteren ekonomik belirsizlik ve ortaya çıkan ekonomik yozlaşma; yatırım kapasitesinin düşmesine, ekonomik kalkınma hızının yavaşlamasına, dış piyasalara yatırımı özendirerek ekonomiden çıkış sürecinin hızlanmasına ve kamu harcamalarının artmasına neden olmaktadır. Bu durum Ordo liberalizminin altında yatan temel felsefe olan; insani hak ve özgürlüklerin korunması ve sosyal eşitliğin sağlanması ile ortaya çıkan serbest piyasanın gerekleri ile ters düşmektedir.

\section{SON NOTLAR}

Leibenstein (1966) tarafindan ortaya atılan X etkinsizliği, veri bir girdi miktarının herhangi bir nedenle maksimum çıktıya ulaşamamasıdır. X etkinsizliğinin geçerli olduğu durumlarda, aynı girdi ile elde edilen cari çıtı seviyesinin, potansiyel seviyeden daha az olacağı vurgulanmaktadır (Çetin, 2010: 187). Kamu tercihi söz konusu olduğunda $\mathrm{X}$ etkinsizliği, büyüyen kamu sektörünün toplumsal ve ekonomik yaşamda tahripkar sonuçlara yol açacağını ifade etmek için kullanılmaktadır.

2 Yatay Kuvvetler Ayrilığı yasama, yürütme ve yargının ayrı birimler olarak devlet gücü içinde hareket etmesini ifade ederken, Dikey Kuvvetler Ayrıllı̆g ise adem-i merkeziyetçi bir yapılanmayla devlet yönetiminin gerçekleştirilmesini vurgulamaktadır. 


\section{KAYNAKLAR}

Akıncı, Merter, Ekonomik Özgürlükler ve Ekonomik Büyüme Arasındaki İlişki, 1. Baskı, Dora Yayıncılık, Bursa 2014.

Aktan, Coşkun C., "Klasik Liberalizm, Neo-Liberalizm ve Libertarianizm", Amme İdaresi Dergisi, Cilt: 28, Say1: 1, 1995, s. 3-27.

Aktan, Coşkun C., Yeni İktisat Okulları, 2. Baskı, Seçkin Yayıncılık, Ankara 2008.

Alesina, Alberto, Şule Özler, Nouriel Roubini and Phillip Swagel, "Political Instability and Economic Growth”, NBER Working Paper, No: 4173, 1992.

Ali, Abdiweli M. - Hodan S. Isse, "Determinants of Economic Corruption: A Cross-Country Comparison”, Cato Journal, Vol: 22, No: 3, 2003, s. 449-466.

Asongu, Simplice A., "Fighting Corruption in Africa: Do Existing Corruption-Control Levels Matter?", International Journal of Development Issues, Vol: 12, No: 1, 2013, 36-52.

Beaud, Olivier, "Anayasa ve Anayasacıllk", Philippe Raynaud ve Stephane Rials (Ed.), Siyaset Felsefesi Sözlüğ̈̈, (ss. 63-74), İletişim Yayınları, İstanbul 2004.

Berggren, Niclas, "The Benefits of Economic Freedom: A Survey", The Independent Review, Vol: 8, No: 2, 2003, s. 193-211.

Billger, Sherrilyn M. - Rajeev K. Goel, "Do Existing Corruption Levels Matter in Controlling Corruption? Cross-Country Quantile Regression Estimates", Journal of Development Economics, Vol: 90, No: 2, 2009, s. 299305.

Brenkert, George G., Political Freedom, Routledge Publishing, London 1991.

Brooks, C. (2008), Introductory Econometrics for Finance (UK: Cambridge University Press 2nd Ed.).

Buchanan, James M., "The Constitution of Economic Policy", American Economic Review, Vol: 77, No: 3, 1987, s. $243-250$.

Campante, Filipe R., Davin Chor and Quoc A. Do, "Instability and the Incentives for Corruption", Economics \& Politics, Vol: 21, No: 1, 2009, s. 42-92.

Campos, Mauro F. - Francesco Giovannoni, "Lobbying, Corruption and Political Influence", Public Choice, Vol: 131, No: 1-2, 2007, s. 1-21.

Charemza, W.W. - Deadman, D.F. (1993), New Directions in Econometric Practice (UK: Edward Elgar Publishing).
Çelik, Fikret - Sefa Usta, "Klasik Liberalizmde 'Özgürlük' ve Liberalizmin Yerel Yönetimlere Bakışı”, Selçuk Üniversitesi Sosyal Bilimler Enstitüsü Dergisi, Say1: 24, 2010, s. 121-135.

Çetin, Tamer, "İktisadi Etkinlik Üzerine Bir Deneme: X Etkinlik Yaklaşımı”, Doğuş Üniversitesi Dergisi, Cilt: 11, Sayı: 2, 2010, s. 183-198.

Çoban, Orhan, "Organize Olmayan Sosyo-Ekonomik Sistemin Organize Bir Kurumu: Rüşvet”, Amme Idaresi Dergisi, Cilt: 32, Say1: 2, 1999, s. 3-13.

Davis, Howard, Political Freedom: Associations, Political Purposes and the Law, Continuum Publishing, New York 2000.

De Vanssay, Xavier - Z. A. Spindler, "Freedom and Growh: Do Constitutions Matter?", Public Choice, Vol: 78, No: 3-4, 1994, s. 359-372.

Del Monte, Alfredo - Erasmo Papagni, “The Determinants of Corruption in Italy: Regional Panel Data Analysis", European Journal of Political Economy, Vol: 23, No: 2, 2007, s. 379-396.

Elbahnasawy, Nasr G. - Charles F. Revier, "The Determinants of Corruption: Cross-Country-Panel-Data Analysis", The Developing Economies, Vol: 50, No: 4, 2012, s. 311-333.

Elliott, Kimberly A., "Corruption as an International Policy Problem: Overview and Recommendations", Kimberly A. Elliott (Ed.), Corruption and the Global Economy, (pp. 175-236), Institute for International Economics, Washington DC 1997.

Ellul, Jacques, The Ethics of Freedom, Wm. B. Eerdmans Publishing, USA 1976.

Evrensel, Ayşe, "Institutional and Economic Determinants of Corruption: A Cross-Section Analysis", Applied Economics Letters, Vol: 17, No: 6, 2010, s. 551-554.

Farr, W. Ken, Richard A. Lord - J. Larry Wolfenbarger, "Economic Freedom, Political Freedom and Economic Well-Being: A Causality Analysis", Cato Journal, Vol: 18, No: 2, 1998, s. 247-262.

Friedman, Milton - Rose D. Friedman, Capitalism and Freedom, 40th Edition, University of Chicago Press, USA 2002.

Gerring, John - Strom C. Thacker, "Political Institutions and Corruption: The Role of Unitarism and Parliamentarism", British Journal of Political Science, Vol: 34, No: 2, 2004, s. 295-330.

Goel, Rajeev K. - Michael A. Nelson, "Economic Freedom Versus Political Freedom: Cross-Country Influences on Corruption", Australian Economic Papers, Vol: 44, No: 2, 2005, s. 121-133. 
Granger, C.W.J. (1964), Spectral Analysis of Economic Time Series (New Jersey: Princeton University Press).

Granger, C.W.J. (1969), "Investigating Causal Relations by Econometric Models and Cross-Spectral Methods", Econometrica, 37(3), s. 424-438.

Gwartney, James - Robert Lawson, "The Concept and Measurement of Economic Freedom", European Journal of Political Economy, Vol: 19, No: 3, 2003, s. 405-430.

Hamilton, J.D. (1994), Time Series Analysis. New Jersey, Princeton University Press.

Hausman, J.A. - Taylor, W.E. (1981), "Panel Data and Unobservable Individual Effects", Econometrica, 49(6), 1377-1398.

Ismail, Aisha - Kashif Rashid, "Time Series Analysis of the Nexus Among Corruption, Political Instability and Judicial Inefficiency in Pakistan", Quality \& Quantity, 2013, DOI: 10.1007/s11135-013-9922-5

Iwasaki, Ichiro - Taku Suzuki, "The Determiants of Corruption in Transition Economies", Economics Letters, Vol: 114, No: 1, 2012, s. 54-60.

Jayasuriya, Kanishka, "The Rule of Law and Regimes of Exception in East Asia”, Asia Research Centre Working Paper, No: 96, 2000.

Judge, G.G. (1985), The Theory and Practice of Econometrics (USA: Wiley 2nd Ed.).

Kao, C. (1999), "Spurious Regression and ResidualBased Tests for Cointegration in Panel Data", Journal of Econometrics, 90(1), s. 1-44.

Kasper, Wolfgang, Ekonomik Özgürlük ve Gelişme, (Çev.: Bahadır Akın), Liberte Yayınları, Ankara 2007.

Kaya, V. - Yılmaz, Ö. (2006), "Bölgesel Enflasyon Bölgesel Büyüme İlişkisi: Türkiye İçin Zaman Serisi ve Panel Veri Analizleri”, İktisat İ̧sletme ve Finans, 21(247), s. 62-78.

Kuşat, Nurdan - Nilgün Dolmacı, "Kamu Tercihi Teorisi Çerçevesinde Seçim Ekonomisi Kavramının Değerlendirilmesi", Cumburiyet Üniversitesi İktisadi ve İdari Bilimler Dergisi, Cilt: 12, Sayı: 1, 2011, 129-146.

Lau, E., Chye, X.-H. - Choong, C.-K. (2011), "Energy-Growth Causality: Asian Countries Revisited", International Journal of Energy Economics and Policy, 1(4), s. $140-149$.

Lederman, Daniel, Norman V. Loayza and Rodrigo R. Soares, "Accountability and Corruption: Political Institutions Matter", Economics \& Politics, Vol: 17, No: 1, 2005, 1-35.
Lee, C.C. (2005), "Energy Consumption and GDP in Developing Countries: A Cointegrated Panel Analysis", Energy Economics, 27(3), s. 415-427.

Mauro, Paolo, "Corruption: Causes, Consequences and Agenda for Further Research", Finance \& Development, Vol: 35, No: 1, 1998, s. 11-14.

Mo, Pak H., "Corruption and Economic Growth", Journal of Comparative Economics, Vol: 29, No: 1, 2001, 66-79.

Montinola, Gabriella R. - Robert W. Jackman, "Sources of Corruption: A Cross-Country Study", British Journal of Political Science, Vol: 32, No: 1, 2002, s. 147-170.

Okun, Arthur M., Equality and Efficiency: The Big Tradeoff, The Brookings Institution Press, Washington DC 1975.

Olson, Mancur, The Rise and Decline of Nations: Economic Growth, Stagflation and Social Rigidities, Yale University Press, New Haven 1982.

Pazarlıoğlu, M.V. - Gürler, Ö.K. (2007), "Telekomünikasyon Yatırımları ve Ekonomik Büyüme: Panel Veri Yaklaşımı", Finans Politik \& Ekonomik Yorumlar, 44(508): s. 35-43.

Pedroni, P. (1999), "Critical Values for Cointegration Tests in Heterogeneous Panels with Multiple Regressors", Oxford Bulletin of Economics and Statistics, 61(S1), s. 653670.

Rabushka, Alvin, "Philosophical Aspects of Economic Freedom”, Walter Block and James C. W. Ahiakpor (Ed), Economic Freedom: Toward a Theory of Measurement, (pp. 23-56), The Fraser Institute, Vancouver 1991.

Raz, Joseph, The Morality of Freedom, Oxford University Press, New York 1986.

Serra, Danila, "Empirical Determinants of Corruption: A Sensitivity Analysis", Public Choice, Vol: 126, No: $1-2,2006$, s. 225-256.

Shabbir, Ghulam - Mumtaz Anwar, "Determinants of Corruption in Developing Countries", The Pakistan Development Review, Vol: 46, No: 4, 2007, s. 751-764.

Svensson, Jakob, "Investment, Property Rights and Political Instability: Theory and Evidence", European Economic Review, Vol: 42, No: 7, 1998, s. 1317-1341.

Şanlısoy, Selim - Recep Kök, "Politik İstikrarsızlık-Ekonomik Büyüme İlişkisi: Türkiye Örneği (19872006)", Dokuz Eylül Üniversitesi İktisadi ve İdari Bilimler Fakültesi Dergisi, Cilt: 25, Sayı: 1, 2010, s. 101-125. 
Tayyar, Ayşegül - Birol Çetin, "Liberal İktisadi Düşüncede Devlet”, Cumburiyet Üniversitesi İktisadi ve İdari Bilimler Dergisi, Cilt: 14, Sayı: 1, 2013, s. 107-120.

Treisman, Daniel, "The Causes of Corruption: A Cross-National Study", Journal of Public Economics, Vol: 76, No: 3, 2000, s. 399-457.

Vanberg, Viktor J., "Market and State: The Perspective of Constitutional Political Economy", Freiburg Discussion Papers on Constitutional Economics, No: 04/10, 2004.
Vatter, Miguel E., Between Form and Event: Machiavelli's Theory of Political Freedom, Kluwer Academic Publishers, Netherlands 2000.

Wooldridge, J.M. (2009), Introductory Econometrics: A Modern Approach (USA: Cengage Learning 4th Ed.).

Yereli, Ahmet B., Ekonomik Özgürlükler ve Türkiye'de Devlet-Birey İlişkisi, Gazi Kitabevi, Ankara 2003. 